University at Buffalo School of Law

Digital Commons @ University at Buffalo School of Law

\title{
Felony Murder and Mens Rea Default Rules: A Study in Statutory Interpretation
}

\author{
Guyora Binder \\ University at Buffalo School of Law
}

Follow this and additional works at: https://digitalcommons.law.buffalo.edu/journal_articles

Part of the Criminal Law Commons

\section{Recommended Citation}

Guyora Binder, Felony Murder and Mens Rea Default Rules: A Study in Statutory Interpretation, 4 Buff. Crim. L. Rev. 399 (2000).

Available at: https://digitalcommons.law.buffalo.edu/journal_articles/284

Published as Guyora Binder, Felony Murder and Mens Rea Default Rules: A Study in Statutory Interpretation, 4 Buff. Crim. L. Rev. 399 (2000). (C) 2000 by the Regents of the University of California. Copying and permissions notice: Authorization to copy this

C. IN COPYRIGHT

This Article is brought to you for free and open access by the Faculty Scholarship at Digital Commons @ University at Buffalo School of Law. It has been accepted for inclusion in Journal Articles by an authorized administrator of Digital Commons @ University at Buffalo School of Law. For more information, please contact lawscholar@buffalo.edu. 


\title{
Felony Murder and Mens Rea Default Rules: A Study in Statutory Interpretation
}

\author{
Guyora Binder*
}

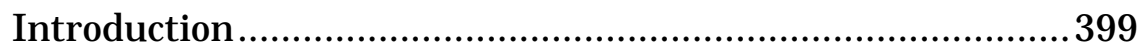

I. The Felony Murder Rule ............................................... 405

II. The Model Penal Code Scheme ....................................408

A. The Default Rule Scheme.........................................408

B. The Fel ony Murder Scheme...................................412

III. Default Rules in the States ..............................................416

IV. Culpability Terms in Fel ony Murder Statutes ................430

V. The Interpretive Problem: Strategies of Evasion.............437

A. The Nonpervasive Default Rule Strategy.................438

B. The Explicit Strict Liability Strategy .......................438

1. Legislative History ..............................................439

2. Doctrine ........................................................439

3. Statutory Structure...........................................440

4. Instrumental or Policy Considerations................441

C. The Implicit Culpability Strategy ..........................441

1. "Criminal Homicide".........................................441

2. Transferred Intent..........................................442

3. Dangerousness...................................................442

4. Proximate Cause ................................................443

VI. The Interpretive Problem in the Courts ........................443

A. Pervasive Recklessness (or I ntent) States.................444

B. Pervasive Negligence or Homicide Default

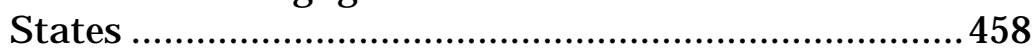

C. Nonpervasive States ..............................................472

D. Summary of Default Rules in the Courts .................480

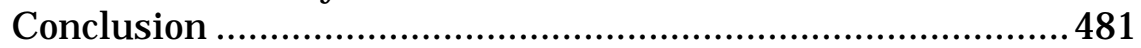

\section{INTRODUCTION}

The Model Penal Code had inspired penal law reform in over thirty states by the early 1980 's, according to its

* Professor of Law, S.U.N.Y. at Buffalo. Thanks to Markus Dubber, Paul Robinson, Robert Weisberg, and J ames Wooten for helpful discussion, and to Hisham Ramadan for research assistance. 
principal drafter, Herbert Wechsler. ${ }^{1}$ One of the Model Penal Code's most influential features is said to be the scheme of culpable mental states developed in its general part. ${ }^{2}$ This scheme distinguishes and defines mental states and associates these mental states with particular conduct, circumstance, and result el ements of offenses and defenses. This scheme is designed to clarify the mental element of each offense and defense and to create options intermediate between purpose and strict liability, while avoiding the confusion created by the traditional terminology of general, specific, transferred and presumed intent. One important feature of the Code's general culpability scheme is a series of default rules, designed to assign a culpable mental state to every conduct, circumstance and result element of each offense and defense. As we shall see, these default rules have been enacted in whole or in part in half of the American states.

By contrast, one of the Code's least influential features is said to be its near abolition of the traditional felony murder rule in its special part. As part of the Code's general disfavoring of strict liability and criminal negligence, the Code conditioned murder liability for killing in the course of crime on recklessness and extreme indifference to human life, thereby assimilating it into other forms of unintentional murder. In so doing, the Code's drafters rejected what they understood to be the fel ony murder rule's imposition of "a form of strict liability for ... homicide." ${ }^{\prime 3}$ It is commonly said that almost every state in the country has retained some form of the felony murder rule and so repudiated the Model Penal Code's

1. See Herbert Wechsler, Foreword to 2 Model Penal Code and Commentaries, at xi (1980).

2. See George P. Fletcher, Reflections on Felony-Murder, 12 Sw. U. L. Rev. 413, 414 (1981) ('The Model Penal Code has stimulated an extraordinary level of legislative activity. In the last two decades thirty-four states have adopted at least some portion of the recommendations embodied in the Model Code. The most popular provisions are those defining the four kinds of culpability. . . .").

3. Model Penal Code $\S 210.1$, pt. II cmt. at 5 (Official Draft and Revised Comments 1980). 
proposed reform. ${ }^{4}$

This article is about the relationship between these two features of the Model Penal Code-that is, between the Code's culpability scheme and its rejection of the felony murder rule. It is also about the apparently inconsistent legislative response to these two features of the Code. The article's premise is that the Model Penal Code's treatment of the felony murder issue flows from its general culpability scheme. That scheme demands culpability for serious crimes like murder. Hence to adopt the general culpability scheme while continuing to embrace the felony murder rule, as traditionally understood, is inconsistent at the level of principle.

But it is not entirely clear whether legislatures have adopted this inconsistent position, because the default rules may alter the meaning of previously enacted felony murder provisions. Thus, in adopting the Model Penal Code's general culpability scheme while substantially retaining their previous statutory definitions of felony murder, some legislatures have created a difficult problem of statutory interpretation. The problem arises from the fact that while felony murder has often been understood as a strict liability offense, statutory definitions of felony murder have traditionally been silent as to its mental element. In retaining their traditionally laconic definitions

4. See Sanford H. Kadish \& Stephen J. Schulhofer, Criminal Law and Its Processes 479 (6th ed. 1995) ("Despite the substantial influence of the Model Penal Code in other areas, it has had a smaller measure of success here: Only New Hampshire adopted the Model Penal Code's formulation ... ; very few legislatures went further and abolished the doctrine...."); J oshua Dressler, Understanding Criminal Law 479 (2d ed. 1995) ("The rule is richly criticized in this country. Nonetheless, the rule 'still thrives' in the United States, and is retained in some form in nearly every state jurisdiction."). Fletcher argues:

Of all the reforms proposed by the Model Penal Code, perhaps none has been less influential than the Model Penal Code's recommendation on the perennial problem of felony-murder. ... Not a single state has adopted the Model Penal Code's proposed reformulation of the felony murder rule. ... By and large... the states that have reformed their criminal codes since 1960 have, first, ignored the recommendations of the Model Penal Code and, second, retained the felony-murder rule as a criterion of liability for the highest degree of criminal homicide.

Fletcher, supra note 2 , at 415. 
of felony murder, legislatures may have thought they were retaining a strict liability offense. Yet in adopting default culpability rules, legislatures may have unwittingly-and unwillingly-reformed the law of felony murder by introducing mental elements.

Thus, one of the purposes of this article is to clarify the law of felony murder in the many states that have adopted some version of the Model Penal Code's default rules. Have states that retained their traditional statutory definitions of fel ony murder thereby retained felony murder as a strict liability offense in defiance of the Model Penal Code? Or have they redefined fel ony murder as a crime of culpability through the Model Penal Code's default rules? This question is complicated, however, by the fact that courts also may have simply overlooked the applicability of default culpability rules to felony murder provisions. Thus we may have to conclude that in some jurisdictions, the el ements of fel ony murder remain to be defined.

To better understand the interpretive problem created by the incorporation of default rules into a code that retains a felony murder rule, let us imagine a code containing the following two provisions:

(1) Criminal liability for an offense requires culpability with respect to every element of that offense. Should the statute defining an offense specify no required culpable mental state with respect to a particular element, the required culpable mental state for that element shall be intent.

(2) Any actor causing the death of a human being in the commission of a felony shall be held strictly liable for murder.

These two provisions flatly contradict one another, generating textual indeterminacy. Which provision controls: the general one, or the specific one? Does it make any difference if one is later in time?

Now consider a code containing provision (1), but 
containing the following modified definition of felony murder:

(2)(a) Any actor causing the death of a human being in the commission of a felony shall be liable for murder.

This provision is a simplified version of the definitions of felony murder found in many codes. These definitions have often been interpreted to predicate fel ony murder on strict liability, but in fact are merely silent as to mental culpability. The deletion of "strictly" from provision (2) appears to remove the contradiction and the resultant ambiguity because the new felony murder provision, (2)(a), no longer clearly imposes strict liability. Since provision (2)(a) specifies no mental state, provision (1) appears to control, and so to condition murder liability on intentionally causing death in the course of a felony.

But conceivably, a court could simply ignore provision (1) and impose strict liability anyway, because felony murder has traditionally been understood as a crime of strict liability. It might treat provision (1) as merely hortatory rhetoric, or as relevant only to the construction of provisions defining new offenses, rather than those previously defined by common law precedent. Or, a court might reason that when a felon causes death accidentally in the course of a felony, culpability "transfers" from the intended (felonious) harm to the unintended death. The court might add that this "transferred" culpability is one traditional meaning of "malice," the mental element of murder at common law. By these means, a court might conclude that holding a felon strictly liable for an accidental death caused in the course of a felony complies with the general requirement of culpability in provision (1). Of course, this kind of transferred intent is not what the drafters of the Model Penal Code meant by "culpability" with respect to every element. But courts may misunderstand or resist the Model Penal Code's culpability scheme.

For another example of this problem, let us now 
introduce a clear statement exception into the requirement of culpability in provision (1):

(1)(a) Criminal liability for an offense requires culpability with respect to every element of that offense, unless strict liability is clearly imposed by the provision defining the offense.

Once again, there appears to be no ambiguity. Since felony murder provision (2)(a) does not clearly impose strict liability, it would appear to fall outside the clear statement exception in (1)(a). But if felony murder has traditionally been understood as a crime of strict liability, an interpreter might conclude that the felony murder provision (2)(a) does "clearly impose" strict liability.

These hypothetical examples illustrate the tension between a general requirement of culpability backed by default culpability standards, and the received expectation that felony murder rule will be a strict liability offense. A legislature borrowing the Model Penal Code's general culpability scheme might be unaware of its implications for the felony murder rule. Hence, we face the arresting possibility that some legislatures that declined to follow the Model Penal Code's approach to felony murder in the special part may have nevertheless abolished or dramatically reformed felony murder through the general part. And just as a legislature might not notice or understand this implication of adopting a general culpability scheme, a court might not notice it either.

This is the paradoxical situation explored in this article. The paradox is important in its own right, in clarifying the law of felony murder in many jurisdictions, and in informing the continuing controversy over the legitimacy of the felony murder rule. But it is also important in that it points to a more general issue concerning the Model Penal Code that is the subject of this symposium. For it points to the possibility that forty years after the Code was drafted, the bench and bar still have not fully assimilated the idea of a criminal statute as a comprehensive and systematic code, with a general part 
governing the structure and definitions of specific offenses.

The article will begin with a brief clarification of the felony murder rule and the claims that such a rule is rejected by the Model Penal Code but nevertheless retained by the states. It will then proceed to explicate the Model Penal Code default rules and the Model Penal Code's approach to felony murder. Next it will delineate the scope of the problem by surveying default rules in the states. It will then examine felony murder provisions in these default rule states. It will analyze the options open to courts in interpreting these felony murder provisions in light of the default rules and, finally, it will examine the performance of the few courts that have confronted the question of the implications of default culpability rules for felony murder.

The article will conclude that while several legislatures and a few courts have understood the applicability of default culpability standards to felony murder provisions, most have not. As a result, there are several states in which the mental element of felony murder is uncertain. In states that have adopted a default culpability standard of negligence, the application of default culpability standards will generally involve little real change in the law, because most states already limit felony murder liability to felonies that inherently impose an unreasonable risk of death. However, in some states that have adopted more exacting default culpability standards-Alaska, Pennsylvania, North Dakota, and Delaware, possibly Kansas and Missouri-dutiful application of that standard will more dramatically alter the law of felony murder.

\section{The Felony Murder Rule}

What is the felony murder rule? There is a great deal of confusion over this question, which makes it hard to assess claims like "the states retain the fel ony murder rule" or "the Model Penal Code rejects the felony murder rule." The problem of assigning a definite meaning to the term "felony murder rule" is illustrated by the following typical 
discussion from Samuel Pillsbury's fine new book on homicide:

In its simplest form, the felony murder rule holds that an individual is guilty of murder, regardless of actual attitude or intent toward killing, if in the course of committing a particular felony he causes another's death. To take the most common example, if a robber kills another in the course of a robbery, he will be liable for felony murder even if the killing is entirely accidental. ... In the United States, the overwhelming majority of jurisdictions retain the fel ony murder doctrine, subject to a variety of restrictions. Some limit the underlying felonies to a short list specified by statute, others to those offenses inherently dangerous, and still other jurisdictions according to whether the felonies are dangerous in the way committed by defendants. ${ }^{5}$

Here is the difficulty posed by this description: Imagine a statute that conditions first degree murder on killing recklessly in the course of a felony and that conditions second degree murder on killing negligently in the course of a felony. Would these two offenses satisfy Pillsbury's definition of the felony murder rule? On the one hand, they impose liability "regardless of . . . intent toward killing," but on the other hand, they don't allow liability for an "entirely accidental killing."

Next, ask yourself how different are these offenses from felony murder as "restricted" in "the overwhelming majority of U.S. jurisdictions." If felony murder requires a death proximately caused by a felonious act dangerous to human life, it requires negligence, at least. And if the danger to human life is very great and very apparent, the death would satisfy some definitions of recklessness. ${ }^{6}$ Felony murder decisions that hold that "accidental" killings in the course of robbery meet the felony murder rule are very often cases in which a defendant alleges that he shot

5. Samuel H. Pillsbury, J udging Evil: Rethinking the Law of Murder and Manslaughter 106, 108 (1998).

6. See Commonwealth v. Welansky, 55 N.E.2d 902 (Mass. 1944) ("grave danger to others must have been apparent"). 
the victim "accidentally" while menacing a vital part of the victim's body with a loaded gun. ${ }^{7}$ Such a shooting is plausibly described as reckless, although it could also be described as merely negligent, on the notion that a defendant threatening to shoot a victim could be unaware of the risk that someone would get shot.

Thus, while discussions of the fel ony murder rule often say it punishes accidental rather than intentional killings in the course of a felony, in most states it punishes killings which are neither intentional nor accidental, but negligent, or possibly reckless. In many of these states, a reckless killing for an antisocial purpose is classified as "extreme indifference" murder, usually murder in the second degree. In such states, felony murder may simply be a category of extreme indifference murder, or it may serve to upgrade some extreme indifference murders to murder in the first degree.

So we can distinguish at least three possible approaches to killing in the course of crime:

(1) Punish it as murder if accompanied by the same mental culpability characterizing other forms of murder.

(2) Punish it as murder if accompanied by a lesser level of culpability than that characterizing other forms of murder.

(3) Punish it as murder per se regardless of mental culpability.

The felony murder rule has traditionally been equated with approach three, but most American felony murder provisions are in fact applied along the lines of approach two. Hence, I would argue that either of these latter two approaches count as variants of the "felony murder rule" but that approach one does not.

7. See, e.g., State v. Humphrey, 351 S.E.2d 613 (W. Va. 1986); State v. Hottle, 476 S.E.2d 200 (W. Va. 1996). 
By these criteria, the American Law Institute's Model Penal Code did not retain the felony murder rule. It instead conditioned felony murder on recklessness and extreme indifference to human life, which are typically indicia of second degree murder. And by these criteria, the great majority of American jurisdictions have probably retained the felony murder rule by effectively conditioning fel ony murder on negligence rather than recklessness.

\section{The Model Penal Code Scheme}

\section{A. The Default Rule Scheme}

To understand the Model Penal Code's approach to felony murder, it is first necessary to review its general interpretive scheme for assigning culpability to criminal offenses. This consists of the following five principles:

1. The Code defines "material elements" as including any conduct, circumstance, or result defining an offense or defense of justification or excuse. ${ }^{8}$

2. The Code permits no strict liability with respect to any material element of a serious offense. ${ }^{9}$ Every material

8. Model Penal Code $\S \S 1.113(9), 1.13(10)$ (Official Draft and Revised Comments 1985).

9. Because some symposium participants expressed incredulity that the Code really forbade strict liability for all serious offenses I must, with apologies, belabor this important point.

Model Penal Code Section 2.02(1) provides:

Minimum Requirements of Culpability: Except as provided in Section 2.05, a person is not guilty of an offense unless he acted purposely, knowingly, recklessly or negligently, as the law may require, with respect to each material element of the offense.

Model Penal Code $\S 2.02(1)$ (Official Draft and Revised Comments 1985).

Model Penal Code Section 2.05 provides:

(1) The requirements of culpability prescribed by ... section 2.02 do not apply to (a) offenses which constitute violations ... or (b) offenses defined by statutes other than the Code, insofar as a legislative purpose to impose absolute liability for such offenses or with respect to any material element 
thereof plainly appears. (2) [u]nless a subsequent statute otherwise provides: (a) when absolute liability is imposed... with respect to any material element of an offense defined by a statute other than the Code and a conviction is based upon such liability, the offense constitutes a violation.

Id. § 2.05(1).

Thus the Code permits strict liability only for offenses defined as violations in the Code, and permits strict liability offenses clearly defined as such outside the Code to be punished only as violations unless a subsequent statute requires otherwise. The Comment to Section 2.02 (Part I, Sections 1.01 to 2.13 p. 229) states:

This section expresses the Code's basic requirement that unless some element of mental culpability is required with respect to each material element of the offense, no valid criminal conviction may be obtained. This requirement is subordinated only to the provision of Section 2.05 for a narrow class of strict liability offenses that are limited to those for which no severer sentence than a fine may be imposed.

Id. $\S 2.02 \mathrm{cmt}$. at 229 .

The Comment to Section 2.05 is similarly unambiguous:

This section makes a frontal attack on absolute or strict liability in the penal law, whenever the offense carries the possibility of criminal conviction, for which a sentence of probation or imprisonment may be imposed. The method used is ... to provide that when conviction rests upon that basis the grade of the offense is reduced to a violation, which is not a 'crime' and ... may result in no sentence other than a fine, or ... forfeiture or other authorized civil penalty. This position is affirmed not only with respect to offenses defined by the penal code; it is superimposed on the entire corpus of the law so far as penal sanctions are involved.... The institute did not doubt that principle is one that should be given force. The liabilities involved are indefensible unless reduced to terms that insulate conviction from the type of moral condemnation that is and ought to be implicit when a sentence of probation or imprisonment may be imposed. . . . This is too fundamental to be compromised.

Id. § $2.05 \mathrm{cmt}$. at $282-83$.

The Drafters of the Code did, by their own admission, violate this proscription of strict liability in one instance. Section 213.6(a) provides strict liability with respect to the attendant circumstance of the victim's age for sex offenses against children under the age of ten. The rationale for this exception would appear to be that chronological age is a proxy for immaturity and incapacity to give meaningful consent. Presumably even an offender who made a reasonable mistake about the precise chronological age of a child under ten could not reasonably believe that the child was mature enough to consent to sex. In this sense, conditioning sex offenses on a very young age establishes a per se negligence rule. For sex offenses conditioned on higher victim ages, the code requires at least negligence with respect to age. The Comment to section 213.6 (Part II Sections 210.0 to 213.6 pp. 412-417) states:

Subsection (1) of Section 213.6 states an exception to the general culpability provisions of Section 2.02. Liability for intercourse with a child less than 10 years old requires no mental state with respect to the child's 
element therefore must be accompanied by a culpable mental state, whether or not that culpable mental state is specified in the statute. Let us call this the pervasive culpability requirement.

3. These culpable mental states are divided into purpose, knowledge, recklessness, and negligence. Each of the culpable mental states in this list includes all that follow. ${ }^{10}$ This arrangement of lesser included culpable mental states is sometimes referred to as the stacking rule.

age.... As a general proposition, one would expect that honest and reasonable mistake as to the critical element of an offense would negate liability.... [But traditionally] statutory rape has been a strict liability offense.... Disallowance of mistake as to age probably relates to the common-law definition of rape as including consensual intercourse with a girl less than 10 years old. Focus on so young an age made strict liability tolerable, for no credible error regarding the age of a child in fact less than 10 years old would render the actor's conduct anything less than a dramatic departure from societal norms... [or] would be sufficient to recharacterize a child of such tender years as an appropriate object of sexual gratification. Of course, it is debatable whether the rule of strict liability is satisfactory even in this circumstance.... The Model Penal Code effects a compromise between the traditional rule disallowing mistake in the law of statutory rape and a general policy against strict liability crimes.... It was thought that strict liability would be acceptable for offenses based on such extreme youth and that in any event any proposed change on this point would encounter political resistance.

Model Penal Code $\S 213.6 \mathrm{cmt}$. at 412-17 (Official Draft and Revised Comments 1985).

What is the significance of section 213.6(1)? On the one hand, the drafters designate it as an exception to section 2.02 which reinforces the conclusion that section 2.02 ordinarily precludes strict liability. On the other hand, if one exception can be created, why not others? One way to reconcile section 213.6(1) with section 2.02 is to see section 213.6(1) as an exception to the Code's method of defining offense elements and culpable mental states, rather than an exception to the principle that every inculpating circumstance must be attended by mental culpability. Another response is to acknowledge that section 213.6(1) violates 2.02(1), but deny that this changes the clearly stated meaning of section 2.02. On this interpretation, section 2.02(1) and section 213.6 simply contradict each other, like provisions (1) and (2) of the hypothetical code discussed above in the introduction.

10. See Model Penal Code $\S 2.02(5)$ (Official Draft and Revised Comments 1985). 
4. When the statutory definition specifies a culpable mental state for the offense as a whole, the Code applies that culpable mental state to all material elements. ${ }^{11}$ Let us call this the distributive default rule.

5. When the statutory definition specifies no culpable mental state, the Code applies recklessness to all material elements. ${ }^{12}$ Let us call this the recklessness default rule.

It should be noted that the pervasive culpability requirement has two aspects. It is, first, a principle of drafting that forbids the integration into the Code of any strict liability offense that can give rise to imprisonment. Second, it is a default rule that applies to offense and defense definitions that fail to assign a culpable mental state to every material el ement. This pervasive culpability default rule requires interpreters to assign a culpable mental state of at least negligence for every material element that is not explicitly assigned a corresponding mental state. Some state codes adopt a pervasive culpability requirement with a clear statement exception. The clear statement exception effectively reduces the pervasive culpability requirement to a pervasive culpability default rule only, and avoids the M.P.C.'s absolute proscription of strict liability offenses. Some state codes adopt a culpability requirement for all offenses, but do not explicitly require that a culpable mental state be assigned to every material element. We may call such a requirement a nonpervasive culpability requirement. Such

11. Section § 2.02(4) provides:

Prescribed Culpability Requirement Applies to All Material Elements. When the law defining an offense prescribes the kind of culpability that is sufficient for the commission of an offense, without distinguishing among the material elements thereof, such provision shall apply to all the material elements of the offense, unless a contrary purpose plainly appears. Id. § 2.02(4).

12. See id. § 2.02(3) ("Culpability Required Unless Otherwise Provided. When the culpability sufficient to establish a material element of an offense is not prescribed by law, such element is established if a person acts purposely, knowingly or recklessly with respect thereto."). 
a requirement has some implications for interpreting offense definitions that fail to specify the culpable mental states assigned to particular elements. It clearly requires that at least one element be assigned a culpable mental state, but it might be read to support assigning every element a culpable mental state. Thus, we can refer to the nonpervasive culpability requirement as a nonpervasive culpability default rule, of uncertain significance.

\section{B. The Fel ony Murder Scheme}

The Code's approach to felony murder is defined by four additional principles:

1. The Code defines criminal homicide as causing death with purpose, knowledge, recklessness, or negligence. ${ }^{13}$ We may call this the homicide culpability requirement, requiring at least negligence with respect to the causation of death for all homicide offenses. This requirement implies a homicide default rule, which would assign a mental culpability of at least negligence to homicide offenses specifying no culpable mental state with respect to the causation of death.

2. Murder is defined as a form of criminal homicide ${ }^{14}$ and includes causing death "recklessly under circumstances manifesting extreme indifference to the value of human life."15

3. These mental states are "presumed" when the defendant or an accomplice commits or attempts robbery, rape, burglary, arson, kidnapping, or escape. ${ }^{16}$

13. Id. $\S 210.1(1)$ ("A person is guilty of criminal homicide if he purposely, knowingly, recklessly, or negligently causes the death of another human being.").

14. Id. § 210.1(2) ("Criminal homicide is murder, manslaughter, or negligent homicide.").

15. Id. § $210.2(1)(b)$.

16. Id. 
4. These "presumptions" permit the jury to find the requisite mental states proven beyond a reasonable doubt, but do not require the jury to so find. In addition, the jury remains obliged to consider countervailing evidence that might give rise to reasonable doubt about the defendant's recklessness and extreme indifference. ${ }^{17}$

This scheme collapses felony murder into gross recklessness murder, and treats the commission of an enumerated dangerous felony as prima facie evidence of gross recklessness. By conditioning fel ony murder liability on a type of mental culpability defining ordinary murder the Code abolishes the felony murder rule.

Note, however, that even without this explicit requirement of extreme indifference to human life, the code could abolish the felony murder rule through its default rules. The crucial rules are the pervasive culpability requirement, the homicide default rule, and the recklessness default rule. The pervasive culpability requirement would prevent the indusion in the Code of a provision explicitly defining felony murder as a crime of strict liability with respect to causation of death. If the code included a felony murder provision silent as to mens rea, the homicide default rule and the pervasive culpability default rule would both require a culpable mental state of at least negligence with respect to this element. The recklessness default rule would go further and require a culpable mental state of recklessness. Since recklessly risking death for a very antisocial purpose such as the commission of a dangerous felony would satisfy many definitions of extreme indifference to human life, ${ }^{18}$ such an

17. Id. $\S 1.12(5)$. When the Code establishes a presumption with respect to any fact that is an element of an offense, it has the following consequences: (a) where there is evidence of the facts that give rise to the presumption, the issue of the existence of the presumed fact must be given to the jury, unless the court is satisfied that the evidence as a whole clearly negatives the presumed fact; and (b) when the issue of the existence of the presumed fact is submitted to the jury, the court shall charge that while the presumed fact must, on all the evidence, be proved beyond a reasonable doubt, the law declares that the jury may regard the facts giving rise to the presumption as sufficient evidence of the presumed fact.

18. See, e.g., Mayes v. People, 106 III. 306 (III. 1883); People v. Protopappas 
approach would again collapse felony murder into extreme indifference murder. In states conditioning first degree murder on causing death in the commission of a dangerous fel ony, the felony murder rule would do nothing more than raise second to first degree murder. In codes without a degree structure, or in codes that condition first degree murder on purposeful killing, the Model Penal Code's default rules would eliminate the felony murder rule altogether, or reduce it to merely one way of defining extreme indifference murder.

Suppose a state adopted the pervasive culpability default rule, and the homicide default rule, but not the recklessness default rule. What would be the effect on felony murder liability? Felony murder liability would be conditioned on at least negligence. As I have already explained, since felony murder is almost always conditioned on causing death in the course of an act foreseeably dangerous to life, it almost always involves at least negligence as a matter of course anyway. Nevertheless, the pervasive culpability default rule and the homicide default rule would both seem to require charging a jury that they must find negligence in order to convict of felony murder. Thus, both rules function as negligence default rules.

What if, in the alternative, a code were to include the recklessness default rule but no pervasive culpability default rule? This could conceivably leave open the question of whether recklessness should apply to all material elements or only some (although Section 2.02(3) is drafted in such a way as to preclude the latter interpretation). Courts in such a jurisdiction would have the option of interpreting a felony murder provision to require no culpability with respect to a resulting death, as long as the predicate felony was a crime of recklessness, knowledge or purpose. ${ }^{19}$ This interpretation of the default

246 Cal. Rptr. 915 (Cal. Ct. App. 1988).

19. Actually, the applicability of a recklessness default rule to felony murder depends on how the felony murder provision is written. Consider a provision that defines as murder, "causing death in the commission or attempt of a forcible 
rule scheme becomes less plausible, however, if the code also includes the distributive rule. The distributive rule is usually formulated so as to distribute to all material el ements any culpable mental state specified for the offense as a whole in the provision defining the offense. Thus, it does not explicitly mandate distributing implied culpable mental states, nor does it, by its own terms require a culpable mental state for every material element. Nevertheless, these interpretive practices seem consistent with the spirit and purpose of the distributive rule. It makes little sense to distribute specified culpable mental states to every element without also distributing implied culpable mental states.

What if a state has adopted the pervasive culpability default rule, but not the pervasive cul pability requirement? Such a state could make felony murder a strict liability crime as long as it did so explicitly. A felony murder provision that was silent on this question would have to be interpreted as requiring at least negligence. But as we saw in the introduction, courts might nevertheless interpret such felony murder provisions as defining strict liability offenses out of habit.

Another possibility is that a state might adopt a nonpervasive culpability requirement. This rule functions as a nonpervasive negligence default rule that might or might not be construed to require negligent causation of death in the fel ony murder context.

felony." The conduct element of this statute is an act causing death and the felony would appear to be an attendant circumstance. If the defendant is required to be at least reckless with respect to one of these elements, he must be at least reckless either as to whether he is in fact committing the act which causes death (shooting a gun, startling an elderly victim), whether death will result, or whether he is committing the predicate forcible felony. It may be argued that section 2.02(2)(c) defines recklessness so as to apply only to circumstance and result elements, not to act elements. If so, defendant must be reckless with respect to either death or the commission or attempt of the felony. Thus technically, the mens rea associated with the predicate felony does not matter, so long as the defendant is aware of a substantial risk of death or of a substantial risk that he is committing or attempting the predicate felony and (arguably) that it is a "forcible" felony. This result raises complex questions about mistake of law and the mens rea of accomplice liability for felony murder. 
One further issue in the application of the Model Penal Code's default rules concerns culpable mental states which are not specified but are instead implied in the definition of conduct or even circumstance elements. Is negligence implied in "proximately causing" or "foreseeably causing" death? Is negligence implied in the "commission" of a felony "dangerous to human life?" It might be argued that the recklessness default rule does not apply to these conduct and circumstance elements, because they have already been assigned culpable mental states by implication. Some jurisdictions have adopted a provision that an offense definition specifying no culpable mental state may nevertheless require one if the proscribed conduct "necessarily involves" a culpable mental state. ${ }^{20}$ We may call this the necessarily involved culpability rule.

\section{Default Rules in the States}

A total of 25 states have adopted some version of the Code's default rules.

Three states, Kansas, Missouri and New J ersey, have adopted intent (as opposed to recklessness) default rules. Of these three, Kansas has adopted an intent default rule and a nonpervasive requirement of either recklessness or intent for almost all felonies. ${ }^{21} \mathrm{New}$ J ersey has adopted a

20. F or example, the New York Penal Law provides:

Although no culpable mental state is expressly designated in a statute defining an offense, a culpable mental state may nevertheless be required for the commission of such offense, or with respect to some or all of the material elements thereof, if the proscribed conduct necessarily involves a culpable mental state. ...

N.Y. Penal Law § 15.15(2)(McKinney 1998).

21. See Kan. Stat. Ann. § 21-3201 (1981):

Criminal intent. (a) Except as otherwise provided, a criminal intent is an essential element of every crime defined by this code. Criminal intent may be established by proof that the conduct of the accused person was intentional or reckless. Proof of intentional conduct shall be required to establish criminal intent, unless the statute defining the crime expressly provides that the prohibited act is criminal if done in a reckless manner.

See also Kan. Stat. Ann. § 21-3204 (1981):

Guilt without criminal intent, when. A person may be guilty of an offense 
pervasive culpability requirement with a clear purpose exception and a knowledge default rule, ${ }^{22}$ and has also adopted the distributive, ${ }^{23}$ necessarily involved culpability, ${ }^{24}$ and homicide default rules. ${ }^{25}$ Missouri, which accepts purpose or knowledge as default mental states, ${ }^{26}$ also has adopted what appears to be a pervasive culpability rule for felonies and misdemeanors, requiring culpability for the conduct, circumstance, or result elements which constitute the material el ements of the offense. ${ }^{27}$ There are

without having criminal intent if the crime is a misdemeanor, cigarette or tobacco infraction or traffic infraction and the statute defining the offense clearly indicates a legislative purpose to impose absolute liability for the conduct described; or a violation of K.S.A. 8-1567 or 8-1567A and amendments thereto.

22. See N.J. Stat. Ann. § 2C:2-2 (West 1998) (“Minimum requirements of culpability. Except as provided in subsection c. (3) of this section, a person is not guilty of an offense unless he acted purposely, knowingly, recklessly or negligently, as the law may require, with respect to each material element of the offense."); see also N.J . Stat. Ann. § 2C:2-2 c. (3) ("A statute defining a crime, unless clearly indicating a legislative intent to impose strict liability, should be construed as defining a crime with the culpability defined in paragraph b. (2) of this section [knowledge]. This provision applies to offenses both inside and outside the code.").

23. See N.J . Stat. Ann. § 2 C:2-2 c. (1) (West 1998) ("When the law defining an offense prescribes the kind of culpability that is sufficient for the commission of an offense, without distinguishing among the material elements thereof, such provision shall apply to all the material elements of the offense, unless a contrary purpose plainly appears.").

24. See id. § 2 C:2-2 c. (3) ("Although no culpable mental state is expressly designated in a statute defining an offense, a culpable mental state may nevertheless be required for the commission of such offense, or with respect to all or some material elements thereof, if the proscribed conduct necessarily involves such culpable mental state.").

25. See id. § 2C:11-5 a. ("A person is guilty of criminal homicide if he purposely, knowingly, recklessly or, under the circumstances set forth in section 2C: 11-5 [causing death by reckless driving], causes the death of a human being. b. Criminal homicide is murder, manslaughter or death by auto.").

26. See Mo. Rev. Stat. § 562.021 (1999):

3. Except as provided in subsection 2 of this section and section 562.026 , if the definition of any offense does not expressly prescribe a culpable mental state for any elements of the offense, a culpable mental state is nonetheless required and is established if a person acts purposely or knowingly; but reckless or criminally negligent acts do not establish such culpable mental state.

27. See id. §562.016:

Culpable mental state. 1. Except as provided in section 562.026, a person 
two exceptions, however. Missouri's Code permits strict liability where "imputation of a culpable mental state is clearly inconsistent with the purpose of the statute defining the offense or may lead to an absurd or unjust result."28 Missouri has also adopted the distributive rule when a culpable mental state is assigned to an offense generally, but has added that when a culpable mental state is assigned to some particular elements, the rest require no mental culpability. ${ }^{29}$

A total of eleven states have adopted recklessness default rules in some form. Hawaii, ${ }^{30}$ Pennsylvania, ${ }^{31}$ and

is not guilty of an offense unless he acts with a culpable mental state, that is, unless he acts purposely or knowingly or recklessly or with criminal negligence, as the statute defining the offense may require with respect to the conduct, the result thereof or the attendant circumstances which constitute the material elements of the crime.

28. Id. § 562.026:

Culpable mental state, when not required. A culpable mental state is not required: (1) If the offense is an infraction and no culpable mental state is prescribed by the statute defining the offense; or (2) If the offense is a felony or misdemeanor and no culpable mental state is prescribed by the statute defining the offense, and imputation of a culpable mental state to the offense is clearly inconsistent with the purpose of the statute defining the offense or may lead to an absurd or unjust result.

29. See id. § 562.021:

Culpable mental state, application. 1. If the definition of any offense prescribes a culpable mental state but does not specify the conduct, attendant circumstances or result to which it applies, the prescribed culpable mental state applies to each such material element. 2. If the definition of an offense prescribes a culpable mental state with regard to a particular element or elements of that offense, the prescribed culpable mental state shall be required only as to specified element or elements, and a culpable mental state shall not be required as to any other element of the offense.

30. See Haw. Rev. Stat. § 702-204 (1993):

Except as provided in section 702-212, a person is not guilty of an offense unless the person acted intentionally, knowingly, recklessly, or negligently, as the law specifies, with respect to each element of the offense. When the state of mind required to establish an element of an offense is not specified by the law, that element is established if, with respect thereto, a person acts intentionally, knowingly, or recklessly.

See also id. § 702-212:

The state of mind requirements prescribed by sections 702-204 and 702-207 through 702-211 do not apply to: (1) An offense which constitutes a violation, unless the state of mind requirement involved is included in the 
Delaware ${ }^{32}$ have adopted the recklessness default rule, the

definition of the violation or a legislative purpose to impose such a requirement plainly appears; or (2) A crime defined by statute other than this Code, insofar as a legislative purpose to impose absolute liability for such offense or with respect to any element thereof plainly appears; § 702$207 . .$. When the definition of an offense specifies the state of mind sufficient for the commission of that offense, without distinguishing among the elements thereof, the specified state of mind shall apply to all elements of the offense, unless a contrary purpose plainly appears.

31. See 18 Pa. Cons. Stat. § 305 (1999):

Limitations on scope of culpability requirements:

(A) When culpability requirements are inapplicable to summary offenses and to offenses defined by other statutes. - The requirements of culpability prescribed by ... section 302 of this title (relating to general requirements of culpability) do not apply to: (1) summary offenses, unless the requirement involved is included in the definition of the offense or the court determines that its application is consistent with effective enforcement of the law defining the offense; or (2) offenses defined by statutes other than this title, in so far as a legislative purpose to impose absolute liability for such offenses or with respect to any material element thereof plainly appears.

(B) Effect of absolute liability in reducing grade of offense to summary offense.- Notwithstanding any other provision of existing law and unless a subsequent statute otherwise provides: (1) when absolute liability is imposed with respect to any material element of an offense defined by a statute other than this title and a conviction is based upon such liability, the offense constitutes a summary offense. ...

See also id. § 302 (1999). General requirements of culpability:

(A) Minimum requirements of culpability.- Except as provided in section 305 of this title... a person is not guilty of an offense unless he acted intentionally, knowingly, recklessly or negligently, as the law may require, with respect to each material element of the offense. ...

(C) Culpability required unless otherwise provided.-When the culpability sufficient to establish a material element of an offense is not prescribed by law, such element is established if a person acts intentionally, knowingly or recklessly with respect thereto.

(D) Prescribed culpability requirement applies to all material elements.When the law defining an offense prescribes the kind of culpability that is sufficient for the commission of an offense, without distinguishing among the material elements thereof, such provision shall apply to all the material elements of the offense, unless a contrary purpose plainly appears.

32. See Del. Code Ann. Tit. $11 \S 251$ (1998):

Proof of state of mind required unless otherwise provided; strict liability.

(a) No person may be found guilty of a criminal offense without proof that the person had the state of mind required by the law defining the offense or by subsection of this section. When the state of mind sufficient to establish an element of an offense is not prescribed by law, that element is 


\section{distributive rule and the pervasive culpability requirement. Illinois, ${ }^{33}$ North Dakota, ${ }^{34}$ and Arkansas ${ }^{35}$ have also adopted}

established if a person acts intentionally, knowingly or recklessly.

It is unnecessary to prove the defendant's state of mind with regard to: (1) Offenses which constitute violations, unless a particular state of mind is included within the definition of the offenses; or (2) Offenses defined by statutes other than this Criminal Code, insofar as a legislative purpose to impose strict liability for such offenses or with respect to any material element thereof plainly appears.

See also id. § 252:

Prescribed state-of-mind requirement applies to all material elements. When a statute defining an offense prescribes the state of mind that is sufficient for the commission of the offense, without distinguishing among the elements thereof, the provision shall apply to all the elements of the offense, unless a contrary legislative purpose plainly appears.

33. See $\S 720$ III. Comp. Stat. 5/4-3 (West 1993):

(a) A person is not guilty of an offense, other than an offense which involves absolute liability, unless, with respect to each element described by the statute defining the offense, he acts while having one of the mental states described in Sections 4-4 through 4-7 [intent, knowledge, recklessness and negligence].

(b) If the statute defining an offense prescribed a particular mental state with respect to the offense as a whole, without distinguishing among the elements thereof, the prescribed mental state applies to each such element. If the statute does not prescribe a particular mental state applicable to an element of an offense (other than an offense which involves absolute liability), any mental state defined in Sections 4-4, 4-5 or 4-6 [intent, knowledge or recklessness] is applicable;

See $\$ 720$ III. Comp. Stat. 5/4-9:

Absolute liability . A person may be guilty of an offense without having, as to each element thereof, one of the mental states described in Sections 4-4 through 4-7 if the offense is a misdemeanor which is not punishable by incarceration or by a fine exceeding $\$ 500$, or the statute defining the offense clearly indicates a legislative purpose to impose absolute liability for the conduct described.

34. N.D. Cent. Code $\S 12.1-02-02.1$ (1997) ("For the purposes of this title, a person engages in conduct.... (e) "Willfully" if he engages in the conduct intentionally, knowingly or recklessly."); see also id. § 12.1-02-02.2 ("If a statute... defining a crime does not specify any culpability and does not provide explicitly that a person may be guilty without culpability, the culpability that is required is willfully."); id. § 12.1-02-02.3:

(a) Except as otherwise expressly provided, where culpability is required, that kind of culpability is required with respect to every element of the conduct and to those attendant circumstances specified in the definition of the offense. . . . (b) Except as otherwise expressly provided, if conduct is an offense if it causes a particular result, the required degree of culpability is required with respect to the result.... (e) A factor as to which it is expressly stated that it must "in fact" exist is a factor for which culpability 
the recklessness default, distributive, and pervasive culpability rules, but have qualified the pervasive culpability rule with a clear statement exception. North Dakota is unusual in providing a formula for such a clear statement: If a statute provides that an element must "in fact" exist or occur, no culpability is required with respect to that element. ${ }^{36}$ Pennsylvania has also adopted the homicide default rule. ${ }^{37}$

Tennessee ${ }^{38}$ has adopted the recklessness default rule and the pervasive culpability default rule. Alaska achieves the same effect by a slightly different scheme. Alaska has adopted a requirement of culpability absent a clear statement of strict liability or legislative intent to hold defendants strictly liable. This default requirement of culpability is not explicitly pervasive. Yet Alaska has also adopted a default rule requiring knowledge with respect to all conduct elements and recklessness with respect to all circumstance and result elements. Thus, the pervasive

is not required.

35. See Ark. Code Ann. § 5-2-203 (Michie 1997):

Culpable mental states-Interpretation of statutes (a) If a statute defining an offense prescribes a culpable mental state and does not clearly indicate that the culpable mental state applies to less than all the elements of the offense, the prescribed culpable mental state applies to each element of the offense. (b) Except as provided in § 5-2-204(2), if the statute defining an offense does not prescribe a culpable mental state, culpability is nonetheless required and is established only if a person acts purposely, knowingly, or recklessly.

36. See discussion of North Dakota Century Code, supra note 34

37. See $18 \mathrm{~Pa}$. Cons. Stat. $\S 2501$ (1999) (“(a) A person is guilty of criminal homicide if he intentionally, knowingly, recklessly or negligently causes the death of another human being. (b) Criminal homicide shall be classified as murder, voluntary manslaughter, or involuntary manslaughter.").

38. See Tenn. Code Ann. § 39-11-301 (1997):

(1) A person commits an offense who acts intentionally, knowingly, recklessly or with criminal negligence, as the definition of the offense requires, with respect to each element of the offense. ... .

A culpable mental state is required within this title unless the definition of an offense plainly dispenses with a mental element.

If the definition of an offense within this title does not plainly dispense with a mental element, intent, knowledge or recklessness suffices to establish the culpable mental state. 


\section{culpability rule is implied. ${ }^{39}$}

Some states have adopted the recklessness default rule without the pervasive culpability rule. Texas ${ }^{40}$ and Utah ${ }^{41}$ have adopted the recklessness default rule and nonpervasive culpability requirements with different variants of clear statement exceptions. Both the Texas and Utah culpability default rules could be read to apply to

\footnotetext{
39. See Alaska Stat. § 11.81 .600 (Michie 1998):

General requirements of culpability... (b) A person is not guilty of an offense unless the person acts with a culpable mental state, except that no culpable mental state must be proved (1) if the description of the offense does not specify a culpable mental state and the offense is (A) a violation; or (B) designated as one of "strict liability"; or (2) if a legislative intent to dispense with the culpable mental state requirement is present.
}

See also id. $\S 11.81 .610$ (b) ("Except as provided in $\S 11.81 .600$ (b) if a provision of law defining an offense does not prescribe a culpable mental state, the culpable mental state that must be proved with respect to (1) conduct is 'knowingly'; and (2) a circumstance or a result is 'recklessly."').

40. See Tex. Penal Code Ann. § 6.02 (West 1977):

Requirement of Culpability. Except as provided in Subsection (b), a person does not commit an offense unless he intentionally, knowingly, recklessly, or with criminal negligence engages in conduct as the definition of the offense requires.

If the definition of an offense does not prescribe a culpable mental state, a culpable mental state is nevertheless required unless the definition plainly dispenses with any mental element.

If the definition of an offense does not prescribe a culpable mental state, but one is nevertheless required under Subsection (b), intent, knowledge, or recklessness suffices to establish criminal responsibility.

41. See Utah Code Ann. § 76-2-101 (1999):

Requirements of criminal conduct and criminal responsibility. No person is guilty of an offense unless his conduct is prohibited by law and:

He acts intentionally, knowingly, recklessly, with criminal negligence, or with a mental state otherwise specified in the statute defining the offense, as the definition of the offense requires; or

His acts constitute an offense involving strict liability. . . .

See also id. § 76-2-102:

Culpable mental state required-Strict liability.

Every offense not involving strict liability shall require a culpable mental state, and when the definition of the offense does not specify a culpable mental state and the offense does not involve strict liability, intent, knowledge, or recklessness shall suffice to establish criminal responsibility. An offense shall involve strict liability if the statute defining the offense clearly indicates a legislative purpose to impose criminal responsibility ... without requiring proof of any culpable mental state. 
conduct elements only but need not be so read. Texas requires culpable "conduct" and Utah requires culpable "action." Yet both Codes define these terms so as to include acting with culpability with respect to the nature of the conduct, or its result, or attendant circumstances..$^{42}$ Texas has also adopted the homicide default rule, ${ }^{43}$ while Utah has adopted a modified version that defines homicide as causing death "[i]ntentionally, knowingly, recklessly, with criminal negligence, or acting with a mental state otherwise specified in the statute defining the offense."14 Ohio has adopted the recklessness default rule and an apparently nonpervasive culpability requirement with a clear statement exception. ${ }^{45}$

A total of seven states-Maine, New Hampshire, New York, Alabama, Kentucky, Oregon and Montana-have what amounts to a negligence default rule. Maine ${ }^{46}$ and

42. See Tex. Penal Code Ann. § 6.03 (West 1977) (giving definitions of culpable mental states); Utah Code Ann. § 76-2-103 (1999) (giving definitions).

43. See Tex. Penal Code Ann. $\S 19.01$ (West 1977) (“(a) A person commits criminal homicide if he intentionally, knowingly, recklessly, or with criminal negligence causes the death of an individual. (b) Criminal homicide is murder, capital murder, manslaughter, or criminally negligent homicide.").

44. See Utah Code Ann. § 76-5-201(1999).

45. See Ohio Rev. Code Ann. § 2901.21 (West 1999):

Requirements for criminal liability. [On or After 7-1-96] (A) Except as provided in division (B) of this section, a person is not guilty of an offense unless ... (2) He has the requisite degree of culpability for each element as to which a culpable mental state is specified by the section defining the offense.

(B) When the section defining an offense does not specify any degree of culpability, and plainly indicates a purpose to impose strict criminal liability for the conduct described in such section, then culpability is not required for a person to be guilty of the offense. When the section neither specifies culpability nor plainly indicates a purpose to impose strict liability, recklessness is sufficient culpability to commit the offense.

46. Me. Rev. Stat. Ann. Tit. 17-a, § 34 (West 1983):

Culpable state of mind as an element. 1 . A person is not guilty of a crime unless that person acted intentionally, knowingly, recklessly or negligently, as the law defining the crime specifies, with respect to each other element of the crime, except as provided in subsection $4 . .$. .

2. When the definition of a crime specifies the state of mind sufficient for the commission of that crime, but without distinguishing among the elements thereof, the specified state of mind applies to all the other elements of the crime, except as provided in subsection. . . . 
New Hampshire ${ }^{47}$ have adopted the pervasive culpability rule and the distributive rule. New York has adopted a pervasive culpability default rule, the distributive rule and also the necessarily involved culpability rule. ${ }^{48}$

3. Unless otherwise expressly provided, a culpable mental state need not be proved with respect to:

A. Any fact that is solely a basis for sentencing classification;

B. Any element of the crime as to which it is expressly stated that it must "in fact" exist;

C. Any element of the crime as to which the statute expressly provides that a person may be guilty without a culpable state of mind as to that element;

D. Any element of the crime as to which a legislative intent to impose liability without a culpable state of mind as to that element otherwise appears;

E. Any criminal statute as to which it is expressly stated to be a "strict liability crime" or otherwise expressly reflects a legislative intent to impose criminal liability without proof by the state of a culpable mental state with respect to any of the elements of the crime; or

F. Any criminal statute as to which a legislative intent to impose liability without a culpable state of mind as to any of the elements of the crime otherwise appears.

4-A. As used in this section, "strict liability crime" means a crime that, as legally defined, does not include a culpable mental state element with respect to any of the elements of the crime and thus proof by the state of a culpable state of mind as to that crime is not required.

47. See N.H. Rev. Stat. Ann. § 62 626:2 (1996):

I. A person is guilty of murder, a felony, or a misdemeanor only if he acts purposely, knowingly, recklessly or negligently, as the law may require, with respect to each material element of the offense.... When the law defining an offense prescribes the kind of culpability that is sufficient for its commission, without distinguishing among the material elements thereof, such culpability shall apply to all the material elements, unless a contrary purpose plainly appears.

48. See N.Y. Penal Law § 15.10 (McKinney 1998):

Requirements for criminal liability in general and for offenses of strict liability and mental culpability.

If . . . conduct is all that is required for commission of a particular offense, or if an offense, or some material element thereof does not require a culpable mental state on the part of the actor, such offense is one of "strict liability." If a culpable mental state on the part of the actor is required with respect to every material element of an offense, such offense is one of mental culpability.

Id. $\S 15.15$ Construction of statutes with respect to culpability requirements:

When the commission of an offense defined in this chapter, or some element of an offense, requires a particular culpable mental state, such 
Alabama has similarly adopted the distributive and necessarily involved culpability rules and has adopted a culpability default rule that may or may not be pervasive. A pervasive culpability rule may be implied in Alabama by a presumption against strict liability offenses, combined with a definition of strict liability offenses as those lacking a culpable mental state with respect to any element. On the other hand, Alabama has paradoxically also defined offenses involving culpability with respect to even one element as offenses of mental culpability. ${ }^{49}$ Alabama has

mental state is ordinarily designated in the statute. ... When one and only one such term appears in a statute defining an offense, it is presumed to apply to every element of the offense unless an intent to limit its application clearly appears.

Although no culpable mental state is expressly designated in a statute defining an offense, a culpable mental state may nevertheless be required for the commission of such offense, or with respect to some or all material elements thereof, if the proscribed conduct necessarily involves such culpable mental state. A statute defining a crime, unless clearly indicating a legislative intent to impose strict liability, should be construed as defining a crime of mental culpability. . . .

49. See Ala. Code§ 13A-2-3 (1994):

Minimum requirement for criminal liability-Strict liability-Mental culpability. The minimum requirement for criminal liability is the performance by a person of conduct which includes a voluntary act or the omission to perform an act which he is physically capable of performing. If that conduct is all that is required for commission of a particular offense, or if an offense or some material element thereof does not require a culpable mental state on the part of the actor, the offense is one of "strict liability." If a culpable mental state on the part of the actor is required with respect to any material element of an offense, the offense is one of "mental culpability."

See also id. § 13A-2-4:

Mental state. (a) When a statute defining an offense prescribes as an element thereof a specified culpable mental state, such mental state is presumed to apply to every element of the offense unless the context thereof indicates to the contrary.

(b) Although no culpable mental state is expressly designated in a statute defining an offense, an appropriate culpable mental state may nevertheless be required for the commission of that offense, or with respect to some or all of the material elements thereof, if the proscribed conduct necessarily involves such culpable mental state. A statute defining a crime, unless clearly indicating a legislative intent to impose strict liability, states a crime of mental culpability. 
also adopted the homicide default rule. ${ }^{50}$

Kentucky has adopted what appears to be a pervasive culpability requirement for felonies in the Criminal Code, and the necessarily involved culpability rule. ${ }^{51}$ Nevertheless, there is room for interpreting the culpability requirement as nonpervasive. Section 501.030(2) of the Kentucky code requires that defendant act "intentionally, knowingly, wantonly or recklessly as the law may require, with respect to each element of the offense." 501.050, which excludes "absolute liability" for felonies, defines "absolute liability" as liability when the defendant does not act with one of those culpable mental states. ${ }^{53}$ These definitions permit the interpretation that the law

50. See id. § 13A-6-1 ("The following terms have the meanings ascribed them by this section: (1) Homicide A person commits criminal homicide if he intentionally, knowingly, recklessly, or with criminal negligence causes the death of another person. ... (3) Criminal homicide Murder, manslaughter, or criminally negligent homicide.").

51. See Ky. Rev. Stat. Ann. § 501.030 (Michie 1999):

Criminal liability. A person is not guilty of a criminal offense unless:

(2) He has engaged in such conduct intentionally, knowingly, wantonly or recklessly as the law may require, with respect to each element of the offense, except that this requirement does not apply to any offense which imposes absolute liability, as defined in KRS 501.050.

Id. § 501.040. Culpability-Construction of statutes

Although no culpable mental state is expressly designated in a statute defining an offense, a culpable mental state may nevertheless be required for the commission of such offense, or with respect to some or all of the material elements thereof, if the proscribed conduct necessarily involves such culpable mental state.

See also id. § 501.050:

Absolute liability.

A person may be guilty of an offense without having one of the culpable mental states defined in $\S 501.020$ only when:

(1) The offense is violation or a misdemeanor as defined in $\S 500.080$ and no particular culpable mental state is included within the definition of the offense; or

(2) The offense is defined by a statute other than this Penal Code and the statute clearly indicates a legislative purpose to impose absolute liability for the conduct described.

52. See also supra note 40 (quoting similar provision in section 6.02 of the Texas Penal Code).

53. See also id. 
need not require a culpable mental state for each offense element. Yet the Model Penal Code section 2.02(1) uses the same "as the law may require" phrase as KRS 501.030(2) and clearly means by it "whichever particular culpable mental state the law requires" rather than meaning "whichever culpable mental state the law requires if the law requires any."

Oregon has adopted the pervasive culpability default rule and the distributive rule. ${ }^{54}$

Montana has adopted the distributive rule and a pervasive culpability default rule, excepting explicitly designated strict liability offenses and, crucially, felony murder. ${ }^{55}$ For felony murder, purpose or knowledge are

54. See Or. Rev. Stat. § 161.095 (1999) (“Requirements of culpability. . . (2) Except as provided in ORS 161.105, a person is not guilty of an offense unless the person acts with a culpable mental state with respect to each material element of the offense that necessarily requires a culpable mental state.").

See also id. § 161.105.

Culpability requirements inapplicable to certain violations and offenses.

(1) Notwithstanding ORS 161.095, a culpable mental state is not required if:

(a) The offense constitutes a violation, unless a culpable mental state is expressly included in the definition of the offense; or

(b) An offense defined by a statute outside the Oregon Criminal Code clearly indicates a legislative intent to dispense with any culpable mental state requirement for the offense or for any material element thereof.

(2) Notwithstanding any other existing law, and unless a statute enacted after J anuary 1, 1972, otherwise provides, an offense defined by a statute outside the Oregon Criminal Code that requires no culpable mental state constitutes a violation.

Id. § 161.115:

Construction of statutes with respect to culpability.

(1) If a statute defining an offense prescribes a culpable mental state but does not specify the element to which it applies, the prescribed culpable mental state applies to each material element of the offense that necessarily requires a culpable mental state.

(2) Except as provided in $\S 161.105$, if a statute defining an offense does not prescribe a culpable mental state, culpability is nonetheless required and is established only if a person acts intentionally, knowingly, recklessly or with criminal negligence.

55. See Mont. Code Ann. § 45-2-103 (1999):

General requirements of criminal act and mental state.

(1) Except for deliberate homicide as defined in 45-5-102(1)(b) [felony murder] or an offense that involves absolute liability, a person is not guilty 


\section{required for the predicate fel ony only. \\ One state, Arizona, has adopted a strict liability default rule, combined with the distributive rule and the necessarily involved culpability rule. ${ }^{56}$

Three states, Colorado ${ }^{57}$, Connecticut, ${ }^{58}$ and Indiana ${ }^{59}$

of an offense unless, with respect to each element described by the statute defining the offense, a person acts while having one of the mental states of knowingly, negligently, or purposely.

(2) In deliberate homicide under 45-5-102(1)(b), the offender must act while having the mental state of purposely or knowingly only as to the underlying felony referred to in $45-5-102(1)(b) . .$. (4) If the statute defining an offense prescribes a particular mental state with respect to the offense as a whole without distinguishing among the elements of the offense, the prescribed mental state applies to each element.

56. See Ariz. Rev. Stat. § 13-202 (1989): Construction of statutes with respect to culpability.

A. If a statute defining an offense prescribes a culpable mental state that is sufficient for commission of the offense without distinguishing among the elements of such offense, the prescribed mental state shall apply to each such element unless a contrary legislative purpose plainly appears.

B. If a statute defining an offense does not expressly prescribe a culpable mental state that is sufficient for commission of the offense, no culpable mental state is required for the commission of such offense, and the offense is one of strict liability unless the proscribed conduct necessarily involves a culpable mental state. ... .

57. See Colo. Rev. Stat. Ann. § 18-1-502 (West 1999):

The minimum requirement for criminal liability is the performance by a person of conduct which includes a voluntary act or the omission to perform an act which he is physically capable of performing. If that conduct is all that is required for commission of a particular offense, or if an offense or some material element thereof does not require a culpable mental state on the part of the actor, the offense is one of "strict liability." If a culpable mental state on the part of the actor is required with respect to any material element of an offense, the offense is one of "mental culpability."

See also id. § 18-1-503:

(1) When the commission of an offense, or some element of an offense, requires a particular culpable mental state, that mental state is ordinarily designated by use of the terms "intentionally," "with intent," "knowingly," "willfully," "recklessly," or "criminal negligence". . . .

(2) Although no culpable mental state is expressly designated in a statute defining an offense, a culpable mental state may nevertheless be required for the commission of that offense, or with respect to some or all of the material elements thereof, if the proscribed conduct necessarily involves such a culpable mental state. ...

(4) When a statute defining an offense prescribes as an element thereof a specified culpable mental state, that mental state is deemed to apply to 
have adopted the distributive rule only, although Colorado al so has adopted the "necessarily involved culpability rule." In addition, Colorado has adopted the same contradictory definitions of strict liability and culpability found in Alabama, although without a pervasive or nonpervasive culpability rule.

Of these twenty-five states, four need concern us no further. Connecticut and Indiana have adopted only the distributive rule, which by itself provides little support for reading a culpable mental state into a felony murder statute. Montana and Arizona have provided in their default rules that no culpable mental state is required with respect to the causation of death for the crime of felony murder.

Nevertheless, Montana is the proverbial exception that proves the rule. By explicitly excepting felony murder from its scheme of culpability rules, Montana's legislature acknowledged the inconsistency between these rules and the doctrine that felons are strictly liable for the causation of death. Clearly the Montana legislature thought that without this unique exception clause, the Model Penal Code's default culpability scheme would abolish or substantially alter the felony murder doctrine. If the twenty-one other legislatures that substantially adopted the Model Penal Code's default rules shared this view, we

every element of the offense unless an intent to limit its application clearly appears.

58. See Conn. Gen. Stat. Ann. § 53a-5 (West 1994):

When the commission of an offense defined in this title, or some element of an offense, requires a particular mental state, such mental state is ordinarily designated in the statute defining the offense by use of the terms "intentionally," "knowingly," "recklessly," or "criminal negligence," or by use of terms, such as "with intent to defraud" and "knowing it to be false," describing a specific kind of intent or knowledge. When one and only one of such terms appears in a statute defining an offense, it is presumed to apply to every element of the offense unless an intent to limit its application clearly appears.

59. See Ind. Code Ann. § 35-41-2-2 § 2(d) (Michie 1998) (“Unless the statute defining the offense provides otherwise, if a kind of culpability is required for commission of an offense, it is required with respect to every material element of the prohibited conduct."). 
would expect to find felony murder provisions conditioning the offense on culpability. And if courts in those states shared this view, we would expect to find decisions reading culpability requirements into definitions of fel ony murder.

Let us now turn to the murder statutes in the twentyone states that concern us. We will first consider default rule states which have avoided ambiguity by specifying the mental element of felony murder in their definitions of that offense. Next we will consider the interpretive problem posed in default rule states by felony murder statutes that do not specify the mental element. Finally we will examine the felony murder statutes that fall into this category and see how they have been construed in the courts.

\section{Culpability Terms in Felony MuRder Statutes}

Seven of our twenty-one remaining default rule states-Arkansas, Delaware, Hawaii, Kentucky, Maine, New Hampshire, and Tennessee-have specified the mental element of killing in the course of a felony.

F our of these states-Hawaii, Kentucky, Arkansas and New Hampshire-have roughly followed the Model Penal Code approach of defining felony murder out of existence. Hawaii, a recklessness default rule state, has no felony murder provision and makes intent to kill an element of all murder. ${ }^{60}$ Kentucky, a negligence default rule state also

60. See Haw. Rev. Stat. Ann. § 707-701 (Michie 1993):

Murder in the first degree.

(1) A person commits the offense of murder in the first degree if the person intentionally or knowingly causes the death of:

(a) More than one person in the same or separate incident;

(b) A peace officer, judge, or prosecutor arising out of the performance of official duties;

(c) A person known by the defendant to be a witness in a criminal prosecution;

(d) A person by a hired killer, in which event both the person hired and the person responsible for hiring the killer shall be punished under this section; or

(e) A person while the defendant was imprisoned. . . .

See also id. § 707-701.5. ("Murder in the second degree. (1) Except as provided in section 707-701, a person commits the offense of murder in the second degree if 
has no felony murder provision and conditions murder on intent to kill or extreme indifference to human life. ${ }^{61}$ Arkansas, a recklessness default rule state, has a felony murder provision, but conditions the offense on extreme indifference to human life. ${ }^{62}$ New Hampshire, a negligence

the person intentionally or knowingly causes the death of another person.").

61. See Ky. Rev. Stat. Ann. § 507.020 (Michie 1999):

Murder.

(1) A person is guilty of murder when:

(a) With intent to cause the death of another person, he causes the death of such person or of a third person; except that in any prosecution a person shall not be guilty under this subsection if he acted under the influence of extreme emotional disturbance for which there was a reasonable explanation or excuse, the reasonableness of which is to be determined from the viewpoint of a person in the defendant's situation under the circumstances as the defendant believed them to be. However, nothing contained in this section shall constitute a defense to a prosecution for or preclude a conviction of manslaughter in the first degree or any other crime;

(b) Including, but not limited to, the operation of a motor vehicle under circumstances manifesting extreme indifference to human life, he wantonly engages in conduct which creates a grave risk of death to another person and thereby causes the death of another person.

62. Ark. Code Ann. § 5-10-102 (Michie 1998):

Murder in the first degree.

(a) A person commits murder in the first degree if:

(1) Acting alone or with one (1) or more other persons, he commits or attempts to commit a felony, and in the course of and in the furtherance of the felony or in immediate flight therefrom, he or an accomplice causes the death of any person under circumstances manifesting extreme indifference to the value of human life; or (2) With a purpose of causing the death of another person, he causes the death of another person; or

(3) He knowingly causes the death of a person fourteen (14) years of age or younger at the time the murder was committed.

(b) It is an affirmative defense to any prosecution under subdivision (a) (1) of this section for an offense in which the defendant was not the only participant that the defendant:

(1)Did not commit the homicidal act or in any way solicit, command,

induce, procure, counsel, or aid its commission; and

(2) Was not armed with a deadly weapon; and

(3) Reasonably believed that no other participant was armed with a deadly

weapon; and

(4) Reasonably believed that no other participant intended to engage in conduct which could result in death or serious physical injury. . . . 
default rule state, has a felony murder provision which closely tracks that of the Model Penal Code. The New Hampshire code conditions first degree murder on killing purposely and with premeditation or knowingly in the attempt or commission of sexual assault, robbery, burglary, arson or assassination. ${ }^{63}$ It conditions second degree murder on recklessness and extreme indifference to the value of human life but provides that these mental states may be presumed from causing death by the use of a deadly weapon in committing any "class A felony." 64 The Code

See also id. § 5-10-103:

Murder in the second degree.

(a) A person commits murder in the second degree if:

(1) He knowingly causes the death of another person under circumstances manifesting extreme indifference to the value of human life; or

(2) With the purpose of injury to another person, he causes the death of any person....

63. See N.H. Rev. Stat. Ann. § 630:1-a (1996):

First Degree Murder.-I. A person is guilty of murder in the first degree if he:

(a) Purposely causes the death of another; or

(b) Knowingly causes the death of:

(1) Another before, after, while engaged in the commission of, or while attempting to commit felonious sexual assault as defined in § 632-A:3;

(2) Another before, after, while engaged in the commission of, or while attempting to commit robbery or burglary while armed with a deadly weapon, the death being caused by the use of such weapon;

(3) Another in perpetrating or attempting to perpetrate arson as defined in § 634:1, I, II, or III;

(4) The president or president-elect or vice-president or vice-president-elect of the United States, the governor or governor-elect of New Hampshire or any state or any member or member-elect of the congress of the United States, or any candidate for such office after such candidate has been nominated at his party's primary, when such killing is motivated by knowledge of the foregoing capacity of the victim.

64. See id. § 630:1-b:

Second Degree Murder.- I. A person is guilty of murder in the second degree if:

(a) He knowingly causes the death of another; or

(b) He causes such death recklessly under circumstances manifesting an extreme indifference to the value of human life. Such recklessness and indifference are presumed if the actor causes the death by the use of a deadly weapon in the commission of, or in an attempt to commit, or in immediate flight after committing or attempting to commit any class $A$ 
further provides that "presumptions" like that contained in the felony murder definition are permissive rather than mandatory. ${ }^{65}$ In other words, the jury may consider causing death through the use of a deadly weapon in the commission of a felony to prove recklessness and extreme indifference to human life, but it need not, and it still must be convinced of the presence of these mental states beyond a reasonable doubt. The practical consequence of this statute has been the abolition of felony murder in New Hampshire. Prosecutions for second degree murder do not appear to avail themselves of the statutory presumption, perhaps because an attack with a deadly weapon supplies prima facie evidence of recklessness and extreme indifference whether or not in perpetration of a felony.

Tennessee, a recklessness default state, requires culpability with respect to each element of an offense, absent a clear statutory statement that an offense is strict liability with respect to some element. Between 1989 and 1995, the Tennessee Code conditioned both first and second degree fel ony murder liability on recklessly causing death. ${ }^{66}$

felony.

65. See id. § 626:7 II:

When this code establishes a presumption with respect to any fact which is an element of an offense, it has the following consequences: (a) When there is evidence of the facts which give rise to the presumption, the issue of the existence of the presumed fact must be submitted to the jury, unless the court is satisfied that the evidence as a whole clearly negatives the presumed fact; and (b) When the issue of the existence of the presumed fact is submitted to the jury, the court shall charge that while the presumed fact must, on all the evidence, be proved beyond a reasonable doubt, the law declares that the jury may regard the facts giving rise to the presumption as sufficient evidence of the presumed fact.

66. 1989 Tenn. Pub. Acts, Ch. 591, at 1197, § 39-13-202:

(a) First degree murder is (1) An intentional, premeditated, and deliberate killing of another; or (2) A reckless killing of another committed in the perpetration or attempt to perpetrate any murder in the first degree, arson, rape, robbery, burglary, theft, kidnapping, aircraft piracy, or the unlawful throwing, placing or discharging of a destructive device or bomb.

See id., at 1202 § 39-13-206:

(a) Second degree murder is (1) A knowing killing of another; or (2) a reckless killing of another which results form the unlawful distribution of opium, or any synthetic or natural salt, compound, derivative or preparation of opium ... when such drug is proven to be the proximate 
In 1995, however, Tennessee eliminated these provisions. The Tennessee Code now specifies that no culpable mental state is required for first degree felony murder liability other than that required for the commission of the enumerated predicate felonies (the traditional enumerated dangerous felonies plus murder, theft, kidnapping, prolonged child abuse, air piracy, and bombing). ${ }^{67}$ When combined with Tennessee's clear statement exception to its culpability requirement, this new first degree felony murder definition achieves the same result as Montana's felony murder exception to its otherwise pervasive culpability requirement. Tennessee's new second degree murder provision includes the distribution of drugs which proximately cause the death of their user ${ }^{68}$ This proximate cause standard may implicitly condition liability on negligence, or the default mental state of recklessness may be required.

Two default rule states, Delaware and Maine, have felony murder definitions requiring negligence. Delaware, a recklessness default state, explicitly conditions second degree felony murder on negligently causing death in the course of any felony. ${ }^{69}$ If death is caused negligently in the

cause of the death of the user.

67. See Tenn. Code Ann. § 39-13-202 (1997):

First degree murder.

(a) First degree murder is:

(1) A premeditated and intentional killing of another;

(2) A killing of another committed in the perpetration of or attempt to perpetrate any first degree murder, arson, rape, robbery, burglary, theft, kidnapping, aggravated child abuse, aggravated child neglect or aircraft piracy; or

(3) A killing of another committed as the result of the unlawful throwing, placing or discharging of a destructive device or bomb.

(b) No culpable mental state is required for conviction under subdivision

(a)(2) or (a)(3) except the intent to commit the enumerated offenses or acts in such subdivisions.

68. See id. § 39-13-210(a)(1)(2) (defining second degree murder as “(1) A knowing killing of another; or (2) A killing of another which results from the unlawful distribution of any Schedule I or Schedule II drug when such drug is the proximate cause of the death of the user.").

69. Del. Code Ann. Tit. 11, § 635 (1998): 
course of an enumerated dangerous felony, or if death is caused recklessly, the resulting liability rises to murder in the first degree. ${ }^{70}$

The Delaware felony murder provisions contain one offense with an uncertain mens rea, however. Section 636 (7) provides for first degree murder liability when the offender "causes the death of another person in order to avoid or prevent the lawful arrest of any person, or in the course of and in furtherance of the commission or attempted commission of escape in the second degree or escape after conviction. ${ }^{\prime 71}$ Because no mental element is specified, the default rule would seem to require a mental element of recklessness, but no Delaware case has as yet construed section 636(7). Conceivably, a court could decline to apply the recklessness default rule to section 636(7), on the ground that it already requires the mental

Murder in the second degree; class B felony.

A person is guilty of murder in the second degree when:

(1) The person recklessly causes the death of another person under circumstances which manifest a cruel, wicked and depraved indifference to human life; or

(2) In the course of and in furtherance of the commission or attempted commission of any felony not specifically enumerated in $\S 636$ of this title or immediate flight therefrom, the person, with criminal negligence, causes the death of another person.

70. See id. § 636:

Murder in the first degree; class A felony.

(a) A person is guilty of murder in the first degree when ....

(2) In the course of and in furtherance of the commission or attempted commission of a felony or immediate flight therefrom, the person recklessly causes the death of another person; ... .

(5) The person causes the death of another person by the use of or detonation of any bomb or similar destructive device;

(6) The person, with criminal negligence, causes the death of another person in the course of and in furtherance of the commission or attempted commission of any degree of rape, unlawful sexual intercourse in the first or second degree, kidnapping, arson in the first degree, robbery in the first degree, burglary in the first degree, or immediate flight therefrom;

(7) The person causes the death of another person in order to avoid or prevent the lawful arrest of any person, or in the course of and in furtherance of the commission or attempted commission of escape in the second degree or escape after conviction.

71. Id. 
states of purpose to prevent an arrest or further an escape. Yet these mental states apply only to the attendant circumstance of the attempted escape or avoidance of custody. They do not apply to the result element of death. According to Delaware Code section 251(b), an element is not established unless a corresponding mental stateeither specified in the definition of the offense, or supplied by the recklessness default rule-is established. And section 232 defines elements as including "those physical acts, attendant circumstances, [and] results" specified in the statute defining the offense. ${ }^{72}$ Hence, the result element of death cannot be established without a corresponding mental state. In addition to these felony murder offenses, Delaware has two additional offenses similar to fel ony murder: first and second degree "murder by abuse." These offenses respectively require the reckless or negligent killing of a child in the course of a pattern of repeated abuse. $^{73}$

In Maine, a state with a negligence default rule, the negligence standard is less explicit but seems clearly implied by a statutory causation standard of foreseeability. ${ }^{74} \mathrm{~A}$ distinct offense, rather than a variant of murder, "felony murder" is a class A crime, the equivalent of manslaughter. Felony murder requires that death be "a

72. Del. Code Ann. tit. 11, § 232 (1998).

73. See id. §§ 633, 634.

74. See Me. Rev. Stat. Ann. tit. 17-a, § 202 (West 1983):

Felony murder 1 . A person is guilty of felony murder if acting alone or with one or more other persons in the commission of, or an attempt to commit, or immediate flight after committing or attempting to commit, murder, robbery, burglary, kidnapping, arson, gross sexual assault, or escape, the person or another participant in fact causes the death of a human being, and the death is a reasonably foreseeable consequence of such commission, attempt or flight. 2. It is an affirmative defense to prosecution under this section that the defendant: A. Did not commit the homicidal act or in any way solicit, command, induce, procure or aid the commission thereof; B. Was not armed with a dangerous weapon, or other weapon which under circumstances indicated a readiness to inflict serious bodily injury; C. Reasonably believed that no other participant was armed with such a weapon; and D. Reasonably believed that no other participant intended to engage in conduct likely to result in death or serious bodily injury. 
reasonably foreseeable consequence" of the commission, attempt, or flight after murder, robbery, burglary, kidnapping arson, rape, or escape. This "reasonably foreseeable" standard dovetails with Maine's definition of criminal negligence with respect to a result as the failure "to be aware of a risk that his conduct will cause such a result" constituting a "gross deviation for the standard of conduct which a reasonable and prudent person would observe."75 Maine also offers an affirmative defense to accomplices who neither caused death nor had reason to know that a weapon would be used.

In sum, seven of the states with default culpability standards that could potentially apply to felony murder provisions in fact specify the mental elements of felony murder. One of these states, Delaware, provides one particular felony murder offense, predicated on escape, without a clearly specified mental el ement.

\section{The Interpretive Problem: Strategies of EVAsion}

We are left with fifteen states (including Delaware) with definitions of fel ony murder silent as to culpability but that nevertheless have mens rea default rules that seem to require culpability. These states are Alabama, Alaska, Colorado, Illinois, Kansas, Missouri, New Jersey, New York, North Dakota, Ohio, Oregon, Pennsylvania, Texas, and Utah, as well as Delaware. Let us turn now to the interpretive problem posed in these states. How may courts deal with the default rules in applying traditional fel ony murder provisions?

The most straightforward response is simply to apply the default culpability standard. But there are three sorts

75. See id. § 35.4 ("In adopting this reasonable foreseeability standard, the statute codified preexisting case law requiring that death foreseeably result from the manner of committing the felony."); see also State v. Reardon, 486 A.2d 112 (Me. 1984); State v. Collins 297 A.2d 620 (Me. 1972) (breaking and entering of dwelling acceptable as predicate felony because of danger of occupants being present and violence resulting); State v. Wallace 333 A.2d 72 (Me. 1975) (stating that sodomy is acceptable as predicate felony where committed forcibly on a small child, because of danger). 
of strategies for evading the default rules in reading felony murder provisions that are silent as to mens rea:

(A) Reading the default rules as nonpervasive;

(B) Reading the felony murder provision as explicitly imposing strict liability, and

(C) Reading the felony murder provision as in fact supplying a culpable mental state.

\section{A. The Nonpervasive Default Rule Strategy}

The simplest general strategy for avoiding application of the default mental state to felony murder is to deny that the default rules actually require a culpable mental state for every element. On this view, the default rule may be satisfied as long as the defendant has the requisite culpable mental state with respect to an attendant circumstance like "in the commission or attempt of a felony." This is a plausible position if the code lacks the pervasive culpability rule, although by no means a necessary one. And it is a confused or dishonest position in a state with the pervasive culpability rule.

\section{B. The Explicit Strict Liability Strategy}

A second general strategy of evasion that is more appealing in pervasive culpability states with a dear statement exception is to read the statute as "dearly indicating a legislative purpose to impose strict liability." Mind you, we have identified the only two statutory provisions in default rule states-Tennessee's definition of first degree murder and Montana's default ruleunequivocally stating that a felony murder offense requires no culpability with respect to the causation of death. So at this point in the analysis, we are talking only about the 
interpretation of statutory provisions which do not clearly indicate an intention to impose strict liability. How can courts read such a "clear" intent into them? There are four methods available: the historical, the doctrinal, the structural, and the instrumental. ${ }^{76}$

\section{Legislative History}

One way is to turn outside the statute to legislative historical evidence of legislative intent. A particularly convincing source of such evidence is the report or commentary of a code drafting commission, although it remains possible to argue that if an intention to impose strict liability has to be demonstrated on this basis it is not clearly indicated by the statute itself.

\section{Doctrine}

A second way to find such a "clearly indicated" legislative intent is to read a modern felony murder provision against the background of the common law or prior legislation. Thus, without attending to the language or structure of the statute one may simply identify a provision punishing the causation of death during a felony as a recognizable "felony murder" provision, assert that the fel ony murder doctrine has traditionally held fel ons strictly liable for deaths caused, and advert to well-worn policy rationales for such a rule, lifted from judicial opinions and treatises. Needless to say, this doctrinalist approach to interpretation is at odds with the "clearly indicated legislative intent" standard. And this reliance on the traditional jurisprudence of felony murder that the drafters

76. These four forms of argument are distinguished and explained in Philip Bobbitt, Constitutional Fate: Theory of the Constitution (1982); Philip Bobbitt, Constitutional Interpretation (1991). For similar accounts, see also Dennis Patterson, Law and Truth (1996); Akhil Reed Amar, The Constitution and Criminal Procedure: First Principles (1997); Akhil Reed Amar, The Bill of Rights: Creation and Reconstruction (1998); William Eskridge, Dynamic Statutory Interpretation (1994). 
of the Model Penal Code so bitterly critiqued is a perverse way to read a felony murder provision embedded in a statute inspired by the Model Penal Code. If we must glean the meaning of a code provision from context, why is pre-code case law a more authoritative context than the official commentary on a model code?

\section{Statutory Structure}

A third way to find such a "clearly indicated" legislative intent is to my mind more legitimate than these first two, but unheard of in the case law. This is to rely on structural interpretation in arguing that conditioning felony murder on the negligent or reckless causation of death would be inconsistent with other features of the law defining fel ony murder or murder more generally.

For example, suppose that the default mental state in a given jurisdiction is a quite demanding one, like purpose or knowledge or intent. Suppose further that the statute defines killing with this mental state as murder and treats killing in the course of a dangerous felony as an aggravator raising first degree murder to a potentially capital offense. It would be inconsistent to read the default mental state of purpose or knowledge or intent into a provision defining causing death in the course of these same predicate felonies as murder. It might seem sensible to read a mental el ement of recklessness or negligence into the offense, but a court could conclude that the default rules make available only the antinomic alternatives of the default mental state, or strict liability. Of course a differently disposed court could find a culpable mental state of negligence implied by the element of causation, particularly if it has available the "necessarily involved" culpability rule.

Consider a second example of structural argument for a "clearly indicated" legislative intent to impose strict liability. Several states have adopted an affirmative defense which excuses from felony murder liability those accomplices in predicate felonies who can prove that they 
neither struck the fatal blow nor had reason to know that any participant would use deadly force or carry a gun. This defense amounts to an affirmative defense for those accomplices who can demonstrate that they could not have foreseen the resulting and death and so were nonnegligent. Such a defense would be redundant if the prosecution were required to prove recklessness or even negligence as part of its prima facie case. Hence, one might argue, the creation of such a defense indicates a legislative intent to impose strict liability rather than a default culpable mental state. The persuasiveness of this argument of course depends on the particular jurisdiction's culpability standards for complicity in general and for felony murder in particular.

\section{Instrumental or Policy Considerations}

A fourth strategy for ascribing a manifest legislative purpose to impose strict liability is to engage in explicit policy argument. For example, a court might assert that the purpose of a felony murder provision must be to deter killings in the course of felonies and that this purpose is best served by a strict liability rule, even though neither of these conclusions is at all obvious. More plausibly, a court might reason that the restriction of felony murder liability to killings in furtherance of inherently dangerous felonies sufficiently insures the culpability of persons convicted of felony murder, so that separate proof of culpability is unnecessary.

\section{The Implicit Culpability Strategy}

A third general strategy of evasion is to read the fel ony murder provision as specifying or implying a culpable mental state. This strategy can take at least four forms.

1. "Criminal Homicide"

One possible strategy is provided by the Model Penal 
Code itself, in providing a general definition of criminal homicide as causing death with purpose, knowledge, recklessness, or negligence and denominating murder as a form of criminal homicide. In jurisdictions with such a provision, it is possible to argue that felony murder is just a particular form and grade of "criminal homicide," and that the mental element of felony murder is therefore supplied by this general definition. Since the "stacking rule" dictates that purpose includes knowledge, knowledge includes recklessness, and recklessness includes negligence, criminal homicide simply means negligent homicide. The offense of criminal homicide can be raised to manslaughter or murder by aggravating mental states (like purpose to kill) or aggravating circumstances (like causing death in the course of a felony).

\section{Transferred Intent}

One form of this strategy involves resurrecting an idea the drafters of the Model Penal Code worked hard to lay to rest, the idea of transferred intent. According to this argument, the felony murder rule involves ascribing the culpable mental state attending the predicate felony to the resulting death. Yet the intent to enter a dwelling at night and there commit the felony of permanently depriving an owner of her property is not an intent to cause death, even if it plausibly implies some other culpable mental state with respect to the risk of death, like recklessness or negligence. The transferred intent argument misses the whole point of Model Penal Code element analysis, which is to assign each act, circumstance, and result its own culpable mental state. Nevertheless, there are better ways of finding implied culpability in felony murder definitions.

\section{Dangerousness}

One of these methods is available if the statutory definition predicates felony murder only on enumerated dangerous felonies, or on any felony dangerous to life, or on 
any "forcible felony" or on an act dangerous to life committed in furtherance of a felony. Here a court can argue that negligence at least, and perhaps even recklessness, is necessarily entailed in the commission of the predicate crime. Another method is available if the statutory definition conditions felony murder on proximately or foreseeably causing death. These terms can be taken as euphemisms for negligence. I should emphasize that these methods of reading negligence standards into felony murder definitions only function as evasions of default culpability in states with recklessness or knowledge or purpose default rules. In states with negligence default rules, they are ways of carrying out the mandate of the default rules, albeit somewhat circuitous ways.

\section{Proximate Cause}

Finally, what if courts read inherent dangerousness limitations and foreseeability standards into fel ony murder definitions that are silent on these subjects? These interpretations of an open-ended felony murder definition are compatible with a negligence default rule, but may not always be motivated or informed by such a rule. Indeed most courts seem blissfully oblivious of the applicability of default rules to felony murder definitions.

\section{The Interpretive Problem in the Courts}

Let us now examine the treatment of the interpretive problem by state courts. As the above discussion indicates, the interpretive problem facing courts is somewhat different depending on whether the default culpability rule is pervasive or nonpervasive and also depending on whether it requires recklessness or knowledge on the one hand, or mere negligence on the other. For our purposes, a homicide default rule functions like a pervasive negligence rule to require negligence with respect to causation of death for fel ony murder. Accordingly, we will consider the 
judicial interpretation of felony murder provisions that are silent with respect to mens rea, in states with three sorts of default rules: pervasive recklessness or intent default rules, pervasive negligence default rules, and nonpervasive default rules.

\section{A. Pervasive Recklessness (or Intent) States}

We will begin with the states that have pervasive default rules requiring a culpable mental state of at least recklessness. Of these, we have already discussed Delaware and its special escape-murder offense. The remaining pervasive recklessness states with felony murder provisions silent as to mens rea are North Dakota, Pennsylvania, Missouri, Illinois, New J ersey, and Alaska.

North Dakota conditions first degree murder liability on causing death in the course and in furtherance of enumerated dangerous felonies, while providing an affirmative defense for accomplices in felonies who could not have foreseen that another participant would kill. ${ }^{77}$ No North Dakota appellate decision has as yet construed the

77. See. N.D. Cent. Code §§ 12.1-16-01(1997):

Murder.

1. A person is guilty of murder, a class AA felony, if the person... c. Acting either alone or with one or more other persons, commits or attempts to commit treason, robbery, burglary, kidnapping, felonious restraint, arson, gross sexual imposition, a felony offense against a child under section 12.1-20-03, 12.1-27.2-02, 12.1-27.2-03, 12.1-27.2-04, or 14-0922 , or escape and, in the course of and in furtherance of such crime or of immediate flight therefrom, the person or any other participant in the crime causes the death of any person. In any prosecution under this subsection in which the defendant was not the only participant in the underlying crime, it is an affirmative defense that the defendant:

(1) Did not commit the homicidal act or in any way solicit, command, induce, procure, counsel, or aid the commission thereof;

(2) Was not armed with a firearm, destructive device, dangerous weapon, or other weapon which under the circumstances indicated a readiness to inflict serious bodily injury;

(3) Reasonably believed that no other participant was armed with such a weapon; and

(4) Reasonably believed that no other participant intended to engage in conduct likely to result in death or serious bodily injury. 
felony murder provisions with respect to mens rea. North Dakota's recklessness default rule requires recklessness unless strict liability is "expressly" imposed and specifically requires culpability with respect to result elements unless otherwise "expressly provided." The same article provides that an offense definition may "expressly" impose strict liability with respect to an element by stating that such element must "in fact" exist or occur. Since no such language appears in North Dakota's felony murder provision, recklessness appears to be the mental element of felony murder. However, North Dakota's affirmative defense makes possible a structural argument that North Dakota's fel ony murder provision "expressly" imposes strict liability. After all, it makes little sense to allow the defense to prove nonnegligence if the prosecution already bears the burden to prove recklessness. Nevertheless, the most straightforward reading of the North Dakota statute would condition fel ony murder on recklessness.

The North Dakota Code was based on the proposed federal criminal code of $1971 .{ }^{78}$ The drafter's official comments on that code shed little further light on the default rules. However, the comment does characterize the section providing that "in fact" means without culpability as a "device for avoiding ambiguity as to whether culpability is required as to certain factors." ${ }^{\prime \prime 9}$ The comment on the fel ony murder definition does not mention the default rules. It says:

Under the traditional felony-murder doctrine, which serves to upgrade certain killings that would normally be, at most, manslaughter (as where defendant did not intend death or knowingly risk grave harm), a purely accidental death becomes murder if it occurs in the course of robbery or some other violent felony. Paragraph (c) would ameliorate the harshness involved in applying the old rule to the person who is not homicidal, but would place a heavy burden on the

78. See Final Report of the National Commission on Reform of Federal Criminal Laws: Proposed New Federal Criminal Code (1971).

79. Id. at 30 . 
defendant to establish his lack of culpability in that regard. ${ }^{80}$

The Drafting Commission seems to assume the new law would apply the old rule of strict liability or negligence, without considering the effect of the code's recklessness default rule. Yet this appearance may be deceiving. The Drafting Commission initially proposed two alternative versions of the felony murder rule: the Model Penal Code's version, which it initially endorsed, and New York's felony murder provision, which it ultimately adopted without further explanation. ${ }^{81}$ While it is tempting to turn to the New York statute in construing the North Dakota felony murder provision, New York has different default rules, requiring only negligence rather than recklessness. The proposed federal code provides a classic example of a drafting commission rejecting the Model Penal Code's formulation of the felony murder rule in the special part, while apparently adopting it through the mens rea default rules of the Model Penal Code's General Part.

For offenses defined within the criminal code itself, Pennsylvania has a pervasive culpability requirement with no exception for a clear statement or legislative purpose to impose strict liability. It has a recklessness default rule and a homicide default rule. Second degree murder is defined as criminal homicide committed in the perpetration of a felony. The perpetration of a felony is defined in turn as the commission, attempt, or flight from the traditional enumerated felonies of robbery, rape, forcible sodomy, arson, burglary, or kidnapping. ${ }^{82}$ Surprisingly, the

80. Id. at 174 .

81. See National Commission on Reform of Federal Criminal Laws, Study Draft of a New Federal Criminal Code $\S 1601 \mathrm{cmt}$. at 164-65 (1970); II Working Papers of the National Commission on Reform of Federal Criminal Laws $\S 1601$ cmt. 826 (Draft 1970).

82. See $18 \mathrm{~Pa}$. Cons. Stat. Ann. § 2502 (West 1999):

Murder.

(b) Murder of the second degree.-A criminal homicide constitutes murder of the second degree when it is committed while defendant was engaged as a principal or an accomplice in the perpetration of a felony.... (d) 
Pennsylvania Supreme Court has never considered the applicability of the recklessness default and homicide default rules to felony murder. At least one lower court has boldly asserted that, even after adoption of the Code, the elements of felony murder in Pennsylvania are still given by the common law. ${ }^{83}$

Only two Pennsylvania cases have addressed the mens rea of felony murder since the 1973 adoption of the default rules, and both do so only in passing. In Commonwealth v. DeHart, an intermediate Pennsylvania court justified the use of enumerated felonies as aggravators for intentional murder by positing that felony murder does not require intent to kill. But rather than clarifying the mental element of felony murder, the court opined that "the intent necessary to establish second degree murder is constructively inferred from the malice incident to the perpetration of an underlying felony." ${ }^{184}$ The court relied, however, on a decision concerning events that preceded the 1973 adoption of the default rules. ${ }^{85}$ On the other hand, the decision of Commonwealth v. Hassein has implicitly acknowledged the applicability of the homicide default rule to felony murder, approving a jury instruction that required proof that the perpetrator "intentionally, knowingly, recklessly or negligently" caused the death of the victim. ${ }^{86}$ In so doing, of course the court implied the inapplicability of the recklessness default rule. This evasion of the recklessness default rule could be defended on the basis of the "criminal homicide" variant of the "implied culpability" strategy. Following this strategy, the court could have reasoned that the definition of criminal

Definitions.-As used in this section the following words and phrases shall have the meanings given to them in this subsection: "Perpetration of a felony." The act of the defendant in engaging in or being an accomplice in the commission of, or an attempt to commit, or flight after committing, or attempting to commit robbery, rape, or deviate sexual intercourse by force or threat of force, arson, burglary or kidnapping.

83. See Commonwealth v. Polimeni, 378 A.2d 1189, 1194 (Pa. 1977).

84. Commonwealth v. DeHart, 516 A.2d 656, 669 (Pa. 1986).

85. See Commonwealth v. Tarver, 426 A.2d 569 (Pa. 1981).

86. Commonwealth v. Hassein, 490 A.2d 438, 454 (Pa. Super. Ct. 1985). 
homicide supplies the mental element of second degree murder, so that there is no need to consult a general default rule. On this reasoning, criminal homicide is one offense with a mens rea of negligence, which is graded on the basis of aggravating circumstances or mental states. Because the Hassein decision harmonizes with the statute and the DeHart decision does not, Hassein should probably be followed in Pennsylvania.

Another place to look for discussions of the mental element of felony murder is in cases on causation of death, because the Pennsylvania Code follows the Model Penal Code in linking causation standards to mental elements. It requires, for example, foreseeability for negligent causation of a result. ${ }^{87}$ Even for strict liability offenses, the Pennsylvania Code requires that proscribed results be "probable consequences" of the defendant's conduct. ${ }^{88}$ One fairly recent case held that foreseeability is not required for causation of death in felony murder cases in Pennsylvania. Remarkably, however, the court did not cite the causation provisions of the Code, and could point to no authority from after the 1973 adoption of the code that was pertinent to the issue. ${ }^{89}$ Obviously, if the Hassein jury instruction is correct, and felony murder requires negligent causation of death, then the requirements of causation are defined by code section 3.03(c) which does indeed require foreseeability.

Missouri's felony murder provision poses a difficult problem of interpretation because it defines the offense unusually broadly, while Missouri also has an unusually elaborate scheme of default rules. The felony murder provision reads as follows:

1. A person commits the crime of murder in the second degree if he:

87. See $18 \mathrm{~Pa}$. Cons. Stat. Ann $\S 303(\mathrm{c})$ (West 1999).

88. Id. § 303(d).

89. Commonwealth v. Evans, 494 A.2d 383 (Pa. Super. Ct. 1985). 
(1) Knowingly causes the death of another person or, with the purpose of causing serious physical injury to another person, causes the death of another person; or (2) Commits or attempts to commit any felony, and, in the perpetration or the attempted perpetration of such felony or in the flight from the perpetration or attempted perpetration of such felony, another person is killed as a result of the perpetration or attempted perpetration of such felony or immediate flight from the perpetration of such felony or attempted perpetration of such felony. ${ }^{90}$

Missouri is unusual in that it does not restrict felony murder by statute to enumerated felonies or felonies dangerous to life.

Missouri has a culpability requirement that appears pervasive, but could be read as nonpervasive. It requires culpability for the conduct, circumstance, or result elements defining the offense, with an exception where culpability would frustrate the purpose of the statute. Missouri also has a knowledge default rule for offenses that specify no culpability term at all and a distributive rule for offenses that specify one culpable mental state without assigning it to particular elements. On the other hand, for offenses that specify a mental element for some but not all elements, Missouri presumes strict liability with respect to those elements. Unfortunately, the arrangement of Missouri's second degree murder definition makes it difficult to determine whether felony murder is a distinct offense with its own definition, or is merely one alternative form of the offense of second degree murder. If felony murder is a distinct offense with no specified culpable mental state, the knowledge default rule would seem to apply. On the other hand, if we read the felony murder clause as part of the definition of the offense of second degree murder, in which culpability terms appear, felony murder looks like a strict liability offense.

Plausible arguments of structure and purpose can be marshaled for either interpretation. Supporting strict 
liability, there is the fact that if felony murder is construed as a crime of culpability, it must also be a crime of knowledge. This would give it the same culpable mental state as the crime of intentional second degree murder defined in the first paragraph of section 565.021, and so would render a separate definition of felony murder superfluous. It would also make Missouri one of the very few states to require a mental element higher than recklessness for murder in the course of dangerous felonies. Supporting culpability, there is the fact that Missouri's felony murder definition is not statutorily predicated on a narrow class of dangerous felonies, nor does it require an act dangerous to life. Thus if Missouri's fel ony murder rule is not read as requiring culpability, it becomes one of the very few unrestricted felony murder rules in the countryperhaps the only one. Because the default rules create a dilemma between the extremes of strict liability and knowledge, they require $\mathrm{M}$ issouri to choose between two versions of the rule which both seem to frustrate the likely purposes of the statute defining the offense.

Because Missouri does not restrict felony murder by statute to enumerated felonies or felonies dangerous to life Missouri's causation standards are particularly important in determining the requisite culpability for felony murder. Yet these causation standards are somewhat murky because the controlling cases involved the now defunct offense of felony murder in the first degree, which was restricted to killing in the course of enumerated dangerous felonies.

Missouri courts have employed a proximate cause test which inculpates all deaths foreseeably resulting from a felony. This includes deaths resulting from resistance to the felony, including the deaths of co-felons, because such resistance is a "foreseeable" and "natural" result of the felony. This foreseeability standard was announced in two opinions of the Missouri Supreme Court. ${ }^{91}$ This standard

91. See State v. Moore, 580 S.W.2d 747 (Mo. 1979); State v. Baker, 607 S.W.2d 153, 154 (Mo. 1980). 
remains controlling law, reiterated in State v. Blunt. ${ }^{92}$ The difficulty is that Missouri courts have not seemed to understand that a foreseeability standard has exculpatory as well as inculpatory implications. Thus in State v. Colenburg, a Court of Appeals affirmed defendant's second degree murder conviction for striking a two-year old child with a stolen car, when the child ran into the street. The theft had occurred seven months previously, but the predicate felony was misappropriation of another's property or "tampering," a continuing offense. As a dissenting opinion noted, the majority ignored the statutory requirement of a causal relationship between the felony and the death. ${ }^{93}$ As a result the majority never considered whether such a death was rendered foreseeably more probable as a result of the misappropriation of the car.

A few Missouri cases have commented more directly on the issue of the mental element of felony murder. A case from the early $80^{\prime}$ s, State v. O'Neal, construed first degree felony murder as a crime of "strict liability." This was arguably true of first degree felony murder as it was then defined. Since all the predicate felonies for first degree murder were inherently dangerous to life, participation in all such felonies was negligent. Hence, it was true that "if the actor has the requisite intent to commit or participate in the underlying felony... no other mental state on his part need be demonstrated. ${ }^{195}$ In 1984, however, Missouri eliminated first degree felony murder, so that O'Neal's pertinence as precedent should have expired. Nevertheless, in State v. Norwood, a Missouri Court of Appeals cited O'Neal's statement in a second degree felony murder case, although it also seemed to suggest that some further culpability was required for felony murder beyond that

92. State v. Blunt, 863 S.W.2d 370 (Mo. Ct. App. 1993).

93. See State v. Colenburg, 773 S.W.2d 184,190 (Mo. Ct. App. 1989).

94. State v. O'Neal, 618 S.W.2d 31, 38 (Mo. 1981) (citing State v. Mullen, 528

S.W.2d 517 (Mo. Ct. App. 1975)).

95. Id. 
required for complicity in the predicate felony. ${ }^{96}$

Alaska, New J ersey, and Illinois courts have relied on legislative drafting commission commentaries to construe their fel ony murder rules.

Alaska punishes causing death in the course and in furtherance of enumerated dangerous felonies, or participating with a street gang in a felony that causes death, as second degree murder ${ }^{97}$ In Alaska, the crucial issue is legislative intent, since the default rule permits the imposition of strict liability where a legislative intent to do so is "present." In Todd v. State, ${ }^{98}$ in holding that a felony murderer could also be punished for the predicate felony, the Alaska Supreme Court commented on the legislature's intent in drafting Alaska's felony murder provision. The court noted that until the current felony murder statute was adopted in 1980, felony murder required intent to kill. This was the traditional rule in Alaska, reconfirmed in the 1970 case of Gray v. State ${ }^{99}$ The court quoted the following passage from the drafter's commentary to the new felony murder provision:

In considering the Revised Code's approach to the felony murder statute, it must be recalled that the purpose of a felony murder rule is to deter all killings during the commission of felonies which involve a high potential for violence. By holding the fel on liable for an unintended and

96. 721 S.W.2d 175 (Mo. Ct. App. 1986).

97. See Alaska Stat § 11.41 .110 (Michie 1998):

Murder in the Second Degree. (a) A person commits the crime of murder in the second degree if . . . (3) acting either alone or with one or more persons, the person commits or attempts to commit arson in the first degree, kidnapping, sexual assault in the first degree, sexual assault in the second degree, burglary in the first degree, escape in the first or second degree, robbery in any degree, or misconduct involving a controlled substance... and, in the course of or in furtherance of that crime, or in immediate flight from that crime, any person causes the death of a person other than one of the participants; or (4) acting with a criminal street gang, the person commits or attempts to commit a crime that is a felony and, in the course of or in furtherance of that crime or in immediate flight from that crime, any person causes the death of a person other than one of the participants.

98. 917 P.2d 674 (Alaska 1996).

99. 463 P.2d 897, 906 (Alaska 1970). 
even accidental death occurring in the course of and in furtherance of a felony, the rule provides a powerful incentive not to commit inherently dangerous crimes, or at the very least to plan and carry out such crimes with increased regard for the physical dangers. For all practical purposes, Alaska does not now have a felony murder rule.... Consequently, an accidental killing occurring during the commission of an enumerated felony does not render the actor guilty of felony murder under the existing statute. Subsection (a)(3) specifically eliminates the Gray requirement that a felon "purposely" kill during the commission of an enumerated felony. ${ }^{100}$

This passage provides clear evidence that the legislature intended to eliminate any requirement of purpose to kill for felony murder. But this would be the automatic effect of a recklessness default rule. Does it show that the legislature clearly intended to eliminate any requirement of culpability? The term "accidental" in this passage might be taken to mean nonculpable, but it might simply mean unintentional. The stated purpose of the rule, deterring killing in the commission of dangerous felonies, might be thought best served by a rule punishing those who are recklessly aware of the risks they impose. On the other hand, the dangerousness of the predicate felony might be thought to supply sufficient culpability and the characterization of the rule as an incentive not to engage in inherently dangerous crimes suggests that liability is automatic for those whose enumerated felonies result in death. Thus, whether felony murder is a strict liability crime or a crime of recklessness remains an open question in Alaska.

New J ersey limits felony murder to enumerated felonies and offers the same affirmative defense for accomplices as North Dakota. ${ }^{101}$ New J ersey is unusual in

100. Todd, supra note 98 , at 678-679 (quoting Alaska Criminal Code Revision, Tentative Draft, pt. 1, pp. 27-29).

101. See N.J . Stat. Ann. § 2C:11-3 (West 1995):

Murder.

a. Except as provided in N.J.S.2C:11-4 criminal homicide constitutes 
that it employs a pervasive knowledge default rule, application of which would clearly eliminate the felony murder rule. Since New J ersey defines potential capital murder in terms of knowledge or purpose and makes the commission of a dangerous felony an aggravator, ${ }^{102}$ application of the knowledge default rule to felony murder would make a hash of New Jersey's murder law. A

murder when: . . .

(3) It is committed when the actor, acting either alone or with one or more other persons, is engaged in the commission of, or an attempt to commit, or flight after committing or attempting to commit robbery, sexual assault, arson, burglary, kidnapping, carjacking, or criminal escape, and in the course of such crime or of immediate flight therefrom, any person causes the death of a person other than one of the participants; except that in any prosecution under this subsection, in which the defendant was not the only participant in the underlying crime, it is an affirmative defense that the defendant: (a) Did not commit the homicidal act or in any way solicit, request, command, importune, cause or aid the commission thereof; and (b) Was not armed with a deadly weapon, or any instrument, article or substance readily capable of causing death or serious physical injury and of a sort not ordinarily carried in public places by law-abiding persons; and

(c) Had no reasonable ground to believe that any other participant was armed with such a weapon, instrument, article or substance; and (d) Had no reasonable ground to believe that any other participant intended to engage in conduct likely to result in death or serious physical injury.

102. See id. § 2C:11-3:

Murder: a. Except as provided in N.J.S.2C:11-4 criminal homicide constitutes murder when: (1) The actor purposely causes death or serious bodily injury resulting in death; or (2) The actor knowingly causes death or serious bodily injury resulting in death. ... . c. Any person convicted under subsection a.(1) or (2) who committed the homicidal act by his own conduct; or who as an accomplice procured the commission of the offense by payment or promise of payment of anything of pecuniary value; or who, as a leader of a narcotics trafficking network as defined in N.J .S.2C:35-3 and in furtherance of a conspiracy enumerated in N.J .S.2C:35-3, commanded or by threat or promise solicited the commission of the offense, shall be sentenced as provided hereinafter: ... .

(2) (a) At the proceeding, the State shall have the burden of establishing beyond a reasonable doubt the existence of any aggravating factors set forth in paragraph (4) of this subsection. ...

(4) The aggravating factors which may be found by the jury or the court are....

(g) The offense was committed while the defendant was engaged in the commission of, or an attempt to commit, or flight after committing or attempting to commit murder, robbery, sexual assault, arson, burglary or kidnapping. 
requirement of knowledge for felony murder would make all felony murders automatically death eligible, while the structure of the statute clearly implies otherwise. In addition, the presence of an affirmative defense for accomplices in felonies that did not foreseeably lead to death suggests that felony murder is otherwise a crime of strict liability. On the other hand, New J ersey also employs a variant of the homicide default rule which clearly precludes strict liability and requires at least recklessness for all homicide offenses. These structural features of the N ew J ersey Code support an argument that application of the knowledge default rule would violate a "contrary purpose" that "plainly appears," even though this contrary purpose is not explicit in the felony murder definition itself.

In the face of these considerations, the New J ersey Supreme Court has characterized felony murder as a crime of strict liability, citing the statement of the Drafting Commission to that effect, but has nevertheless imposed a foreseeability standard that it characterizes as a requirement of negligence. The controlling case is State $v$. Martin. ${ }^{103}$ The Court pointed out that the N ew J ersey Code follows the Model Penal Code in providing a special causation standard for strict liability offenses, according to which the prohibited result must be the "probable consequence" of defendant's conduct. The court reasoned that felony murder liability therefore requires that a death must be "the probable consequence of the commission of the felony." ${ }^{104}$ In explicating this probable consequence standard, the court equates it with "proximate cause,"105 endorses the prosecution's view that this requires that death be "foreseeable,",106 and the defense's view that it may not be "accidental," 107 and endorses an official comment on

103. 573 A.2d 1359 (N.J . 1990).

104. Id. at 1371. See also Model Penal Code § 2.03(4) (Official Draft and Revised Comments 1985).

105. State v. Martin, 573 A.2d at 1373.

106. Id.

107. Id. 
Model Penal Code section 2.06 equating the "probable consequence" and "reasonably foreseeable" standards, as interchangeable standards of "negligence"108 The court concludes that these sources indicate a legislative intent to require "foreseeability," but concedes that the legislature deliberately avoided the term "proximate cause."109 It suggests instructing juries that felons can only be held causally responsible for deaths that were not "too remote, accidental in occurrence, or dependent on another's volition to have a just bearing on the defendant's culpability." 110 The court argues that a killing by one resisting an enumerated dangerous felony would be justly punishable under this standard because it would be "the foreseeable result of the risk created by the felon." ${ }^{\prime 11}$

Thus, the court combines structural, historical and instrumental considerations in evading the knowledge default rule, but partially deferring to the homicide default rule. Ultimately, however, the court's solution fails because New J ersey's version of the homicide default rule clearly requires at least recklessness for "criminal homicide" and its definition of felony murder defines it as "criminal homicide" in the course of enumerated felonies.

Illinois has a pervasive recklessness default rule, with an exception if a "legislative purpose" to impose strict liability is "clearly" indicated in the statute itself. Illinois predicates first degree murder on killing by causing death in the commission or attempt of a "forcible felony," 112

108. Id. at 1374; see also Model Penal Code $\S 2.06$ n.42, at 312 (Official Draft and Revised Comments 1985).

109. State v. Martin, 573 A.2d at 1375.

110. Id.

111. Id.

112. § 720 III. Comp. Stat. Ann. 5/9-1 (West 1993):

First degree Murder ... (a) A person who kills an individual without lawful justification commits first degree murder if, in performing the acts which cause the death: (1) he either intends to kill or do great bodily harm to that individual or another, or knows that such acts will cause death to that individual or another; or (2) he knows that such acts create a strong probability of death or great bodily harm to that individual or another; or (3) he is attempting or committing a forcible felony other than second degree murder. . . . 
defined as a list of enumerated felonies "and any other felony which involves the use or threat of physical force or violence. . .."113 Illinois courts have defined a forcible fel ony as one which involves the use or threat of force under the particular circumstances of its commission. ${ }^{114}$ The statute does not of course "clearly" indicate a legislative intent to impose strict liability. Nevertheless, the conditioning of felony murder on a "forcible" felony could be construed to obviate any additional mental element, on the grounds that culpability with respect to the risk of death is already inherent in the use or threat of force. This is really an "implied culpability" strategy rather than an "explicit strict liability" strategy. Such an approach was taken by the statute's drafters and ultimately by the Illinois courts.

The felony murder statute was drafted by a committee jointly appointed by the state Supreme Court and the state Bar Association, which forwarded it to the legislature with a report. This report stated that:

while a good argument may be made for eliminating the felony-murder provision altogether, it is well established in Illinois to the extent of recognizing the forcible felony as so inherently dangerous that a homicide occurring in the course thereof, even though accidentally, should be held without further proof to be within the 'strong probability' classification of murder. ${ }^{115}$

In People v. McEwen, an appellate court explained:

[I]n Illinois, a party acts with sufficient knowledge in a murder case if ... he knows his conduct creates a strong probability of death or great bodily harm.... [A] killing constitutes felony murder where it is shown that an actor intentionally brought about the death of another or that the actor had knowl edge that his conduct was practically certain to cause death or created a strong possibility that death

113. Id. $5 / 2-8$.

114. People v. Golson, 207 N.E.2d 68 (III. 1965).

115. §720 III. Comp. Stat. Ann. 5/9-1 (West 1993) (Criminal Code of 1961 Committee cmt. at 15) (emphasis added). 
would result . . . even if [death resulted] accidentally. ${ }^{116}$

The felony murder statute, as interpreted by the Committee commentary, presumes knowledge of a strong probability of bodily harm for forcible felonies. Hence, it is not really conditioned on recklessness, but rather on negligence. This notion of forcible felony is fraught with difficulty. In People v. Smith, for example, defendants ran over a victim while speeding away after being interrupted while burglarizing railroad cars. The only "force" used during this burglary was the collision itself. ${ }^{117}$ Illinois courts have consistently defined causation of death in terms of proximate cause, requiring that death be a "direct and foreseeable consequence" of a forcible felony. ${ }^{118}$ Unfortunately, Illinois courts have not always taken the requirement of foreseeable causation seriously as a limitation on liability. ${ }^{119}$

Note that not a single state supreme court has actually applied recklessness default rules to construe a felony murder provision that is silent as to mens rea, although North Dakota has not yet considered the question. Only the New J ersey courts adverted to the general default rules, while one Pennsylvania decision referred implicitly to the homicide default rule.

\section{B. Pervasive Negl igence or Homici de Default States}

Next, let us consider four states that would appear to have pervasive negligence rules or homicide default rules: New York, Alabama, Texas, and Oregon.

New York has a pervasive negligence default rule with a "clear legislative intent" exception and a "necessarily involved" culpability rule. New York has had no cases

116. People v. McEwen, 510 N.E.2d 74, 78 (III. App. Ct. 1987) (citing People v. Guest, 503 N.E.2d 255 (III. 1986)).

117. People v. Smith, 713 N.E.2d 140 (III. App. Ct. 1999).

118. People v. Lowery, 687 N.E.2d 973, 977 (III. 1997).

119. See People v. Davis, 527 N.E.2d 552, 557 (III. App. Ct. 1988); People v. J enkins, 545 N.E.2d 986, 995 (III. App. Ct. 1989). 
addressing the applicability of these rules to fel ony murder. New York does predicate felony murder on enumerated dangerous felonies and provides a defense for accomplices to felonies resulting in unforeseeable deaths. ${ }^{120} \mathrm{New}$ York courts have two stratagems available for evading the default negligence rule. One is a structural argument that the affirmative defense for accomplices manifests a "clear legislative intent" to impose strict liability. An implied culpability argument is also available. A court could argue that juries need not separately find negligence with respect to the risk of death because all of the predicate felonies "necessarily involve" such negligence. On the other hand, the "necessarily involved" rule could be a source of an argument for culpability, on the ground that "causing" death requires that death is foreseeable, and so presupposes negligence. The New York Penal Law has no general provisions on causation, but New York cases have made clear that causation of death requires foreseeability. ${ }^{121}$ This has been confirmed in the context of fel ony murder. ${ }^{122}$

120. See N.Y. Penal Law $\S 125.25$ (McKinney 1998):

Murder in the second degree. A person is guilty of murder in the second degree when: ... 3. Acting either alone or with one or more other persons, he commits or attempts to commit robbery, burglary, kidnapping, arson, rape in the first degree, sodomy in the first degree, sexual abuse in the first degree, aggravated sexual abuse, escape in the first degree, or escape in the second degree, and, in the course of and in furtherance of such crime or of immediate flight therefrom, he, or another participant, if there be any, causes the death of a person other than one of the participants; except that in any prosecution under this subdivision, in which the defendant was not the only participant in the underlying crime, it is an affirmative defense that the defendant: (a) Did not commit the homicidal act or in any way solicit, request, command, importune, cause or aid the commission thereof; and (b) Was not armed with a deadly weapon, or any instrument, article or substance readily capable of causing death or serious physical injury and of a sort not ordinarily carried in public places by law-abiding persons; and (c) $\mathrm{Had}$ no reasonable ground to believe that any other participant was armed with such a weapon, instrument, article or substance; and (d) $\mathrm{Had}$ no reasonable ground to believe that any other participant intended to engage in conduct likely to result in death or serious physical injury; . . . .

121. See People v. Kibbe, 321 N.E. 2d 773 (N.Y. 1974).

122. See People v. Matos, 634 N.E.2d 157 (N.Y. 1994); People v. Hernandez, 624 N.E.2d 661 (N.Y. 1993). 
Alabama's scheme of default rules is very similar to New York's. One significant difference is that while the Alabama Code classifies offenses as strict liability if they lack culpability with respect to any element, it also classifies offenses as offenses of culpability if they require culpability with respect to any element. Thus, it is less clear that Alabama's presumption of culpability is pervasive. On the other hand, Alabama has the homicide default rule. Like New York, Alabama has the "necessarily involved" rule. All three rules would be satisfied by a mental element of negligence. The current Alabama statute conditions felony murder liability on causing death in the course of enumerated dangerous felonies "or any other felony clearly dangerous to human life."123 The official commentary on this provision explains this requirement of dangerousness to life as a requirement of foreseeability and reasons that an unrestricted felony murder rule-punishing unforeseeable deaths-is no longer defensible. At the same time, the commentators decline to require "subjective" awareness of the risk of death. ${ }^{124}$ Thus, without mentioning the negligence default

123. Ala. Code §13A-6-1 (1994) ("Definitions. The following terms shall have the meanings ascribed to them by this section: (1) Homicide. A person commits criminal homicide if he intentionally, knowingly, recklessly or with criminal negligence causes the death of another person. ... (3) Criminal homicide. Murder, manslaughter, or criminally negligent homicide.").

See also id. § 13A-6-2:

Murder.(a) A person commits the crime of murder if: ... (3) He commits or attempts to commit arson in the first degree, burglary in the first or second degree, escape in the first degree, kidnapping in the first degree, rape in the first degree, robbery in any degree, sodomy in the first degree or any other felony clearly dangerous to human life and, in the course of and in furtherance of the crime that he is committing or attempting to commit, or in immediate flight therefrom, he, or another participant if there be any, causes the death of any person.

124. See Ala. Code $\S 13 A-6-2 \mathrm{cmt}$. at 256 (1994):

Under a wholly unrestricted felony-murder rule, defendants may be held liable for the most serious crime known, which was neither intended nor foreseeable. The underlying rationale that defendant has shown himself to be a rationale that defendant has shown himself to be a "bad person," and that this is enough to exclude arguments bearing on the gravity of the harm actually committed, probably was more defensible at early common law when legal conceptions were rotted in simpler moral attitudes. Today a 
rules, the official commentary appears to reconcile the felony murder rule with them. No Alabama felony murder cases have considered whether mental culpability is required with respect to the risk of death. ${ }^{125}$

Felony murder poses a particularly complex interpretive problem in Texas, meriting extensive discussion. Texas has an apparently nonpervasive recklessness rule and a homicide default rule. Section 6.02 of the Texas Penal Code provides the conduct defining all offenses must be committed with the culpable mental state of intent, knowledge, recklessness, or negligence with respect to the conduct required by the definition the offense, unless the definition of an offense "plainly dispenses with any mental element." It further provides that if no mental element is specified in the definition of an offense, a mental element of recklessness, knowledge, or intent must be inferred. Section 6.03 (c) implies however, that conduct is reckless only if it is reckless with respect to a result or attendant circumstance. In the face of this murky default rule scheme, the Texas courts appear to have developed a practice of classifying offenses as either "conduct" offenses or "result" offenses, and therefore requiring culpability with respect to either the conduct or result only. This practice of arbitrarily categorizing some objective elements as essential and others as inessential frustrates the purpose of the Model Penal Code culpability scheme, which was designed to avoid this sort of unpredictable, ad hoc construction of the mental element of offenses. And the scheme of "conduct offenses" and "result

more dominant rationale in the justification of, at least, a restricted version of the rule is that defendant has shown that he is a "dangerous person" who has knowingly engaged in a dangerous crime that by its very nature is highly susceptible of causing death and which, in fact, did cause death. Such departure from a subjective test of criminal liability is justified for the protection of the public.

125. One Alabama case cites Wharton to the effect that the felony murder doctrine involves a "transfer" of malice from an intended felony to an unintended death. Yet the holding in the case is that felony murderers must intend to commit the felony, not that they need have no culpability at all with respect to death. See Bates v. State, 461 So.2d 5 (Ala. 1984). 
offenses" proves very awkward in dealing with Texas' unusually complex definition of felony murder.

Texas Penal Code section 19.02(b)(3) defines murder as including causing death by committing or attempting an act clearly dangerous to human life in the course of and in furtherance of committing or attempting a felony other than manslaughter. ${ }^{126}$ Is this a "conduct offense?" Is this a "result offense?" On its face the offense involves two conduct elements: "commits or attempts to commit a felony," and "commits or attempts to commit an act clearly dangerous to human life." The danger to human life appears to be an attendant circumstance, and the clarity of the danger could be either a circumstance element or a mental element (of negligence or recklessness). "Causing death" is a result element. Supporting a characterization of section 19.02(a)(3) murder as a "result crime" is the fact that section 19.01 classifies murder as a form of criminal homicide which it defines as "intentionally, knowingly, recklessly, or with criminal negligence caus[ing] the death of an individual."

Taking the culpability requirement of section 6.02 at face value, it applies to all conduct elements required by the definition the offense, unless that definition plainly dispenses with a requirement of mens rea. Since committing an act dangerous to life is such a conduct element it would appear to require a mental state. Does the code specify the mental element in requiring that the act be "clearly" dangerous? If "clearly" dangerous means that the danger must be clear to the defendant, then the act must be reckless. If clearly dangerous means the danger must be clear to the average or reasonable person

126. Tex. Penal Code Ann. § 19.01 (West 1977):

Offenses against the person chapter 19. Criminal Homicide. (b) A person commits an offense if he....

(3) commits or attempts to commit a felony, other than manslaughter, and in the course of and in furtherance of the commission or attempt, or in immediate flight from the commission or attempt, he commits or attempts to commit an act clearly dangerous to human life that causes the death of an individual. 
then the act must be negligent. If "clearly" is not a culpable mental state, however, then no mental state is specified and the act must be committed recklessly with respect to either the result element of causing death or the circumstance element of dangerousness to life. Does the Code specify any mental element with respect to the result element of causing death? Had the Code used the term of art "criminal homicide" (as the Pennsylvania Code does) it would have arguably defined the mental element as negligence. But it did not use this term of art in the definition of murder itself.

On the other hand, can it be said that the Code "plainly" dispenses with a mental element for felony murder? The requirement that the felony murderer commit an act "clearly dangerous to human life" and the definition of "criminal homicide" as including murder and requiring the culpable causation of death precludes any conclusion that the text plainly dispenses with a mental element. While the Texas culpability requirement involves an exception for clear statements in the text rather than for clear expressions of legislative intent, there is one relevant legislative historical datum. A "practice commentary" written by attorneys involved in the drafting of the Code and based on "committee comments" circulated to legislators with drafts of the code was published with the code. The comment on what is now section 19.02 (b)(3) stated that:

Although it may contract the scope of the [preexisting] felony murder doctrine, the chief aim of Section 19.02(a)(3) is clarification. Under it the mere attempt or commission of a felony no longer suffices to construct intent or knowledge: the actor must kill while attempting or committing an act clearly dangerous to human life in the course or furtherance of the felony or in immediate flight therefrom. As most fel ony murder prosecutions today involve killings committed while the felon is engaged in highly dangerous conduct, however, section 19.02 (a)(3)'s restatement of the doctrine 
will probably effect little change in practice. ${ }^{127}$

Does this passage "plainly" indicate a legislative intent to retain the common law fel ony murder rule and dispense with mens rea with respect to the risk of death? Hardly. It opines that the addition of new elements to the offense will make little difference to the success of felony murder prosecutions. Such a statement has no purpose unless the traditional definition of felony murder is being changed by the addition of new elements. It does not clarify whether the new statute requires more elements in order to "construct intent or knowledge" or whether it substitutes a mens rea of negligence or recklessness for constructed intent.

In the 1977 case of State v. Rodriguez, ${ }^{128}$ a Texas Court of Criminal Appeals issued a confused opinion construing the felony murder provision according to a theory of transferred intent. The Court stated:

From a consideration of these sections together, it logically follows that because s 19.02(a)(3) is silent as to, and does not plainly dispense with, the culpable mental state required for the underlying felony committed or attempted, s 6.02(b) mandates that the culpable mental state shall ... be one of intent, knowledge, or recklessness. Upon the establishment of the underlying committed or attempted fel ony embracing the requisite mental element, s 19.02(a)(3) then declares that an act which is committed in the course and in furtherance of, or in immediate flight from, the underlying committed or attempted felony and which is clearly dangerous to human life and causes death shall constitute murder. Thus, the culpable mental state for the act of murder is supplied by the underlying committed or attempted felony giving rise to the act. The transference of the mental element establishing criminal responsibility for the original act to the resulting act conforms to and preserves the traditional mens rea requirement of the 
common law. ${ }^{129}$

This passage presents several problems. First, the "traditional mens rea requirement of the common law" seems irrelevant in light of the then recent passage of a code specifying the mental elements of offenses. Second, and more important, the commission of a felony is not the only "conduct" element defining the offense. Committing an act clearly dangerous to human life is also a conduct element requiring a culpable mental state (if indeed "clear danger" is not itself a culpable mental state). One could read the above passage to require that these conduct elements be accompanied by the same culpable mental state as the predicate felony, except for the fact that the court approved a jury instruction requiring only a finding that the predicate fel ony be committed intentionally. This instruction did not require intentional imposition of danger or intentional causation of death. ${ }^{130}$ The Rodriguez court used the transferred intent variant of the implied culpability strategy for evading the Texas Code's default rules. The Rodriguez court appeared to treat felony murder neither as a "conduct offense" nor as a "result offense." In defiance of section 6.02, the court apparently ignored the language "defining the offense" and simply preserved the common law understanding of felony murder. On the other hand, Rodriguez might be read to require that the predicate felony must involve a culpable mental state of recklessness with respect to the risk of death. If so, then culpability could indeed be "transferred" from the predicate fel ony to the resulting death without violating the Code's culpability scheme, because the requisite culpability for the predicate felony would already include culpability with respect to the resulting death.

Three years later, in Kuykendall v. State, a criminal appeals court held that "[c]riminally negligent homicide being a potentially lesser included offense in [intentional 
and intent to injure murder,]. . . it is likewise a prospective lesser included offense of felony murder. ..." 131 The court rejected the state's argument that "'an act dearly dangerous to human life' and conduct amounting to criminal negligence [are] distinctly different and unrelated facts." ${ }^{\prime 32}$ The court disapproved the following analysis:

In determining whether or not a person acts with criminal negligence the fact finder is asked to determine whether the actor ought to have been aware that under the circumstances his conduct posed a substantial and unjustifiable risk constituting a gross deviation from ordinary care. Stated another way, whether the actor should have known or foreseen the results of his conduct. No such inquiry is made by the fact-finder in determining any of the elements of felony-murder. The essence of the felony murder doctrine is that when an individual is engaged in the commission of a felony, he is responsible for the results of his conduct as a matter of law. ... . ${ }^{133}$

The Kuykendall court thereby implied that causing death as a result of committing an act clearly dangerous entails foreseeably-and so negligently-causing death.

The following year, however, the Texas Court of Criminal Appeals reversed field again in Ex parte Easter. ${ }^{134}$ Easter objected to a murder indictment which charged him with causing a baby's death by an act clearly dangerous to human life in the course of committing the felony of negligent injury to a child. The indictment did not specify that he must have acted culpably in committing the act clearly dangerous to human life. Citing Rodriguez, the court held that "[t]he felony murder rule as now embodied in the present Penal Code dispenses with inquiry into the mens rea accompanying the homicide itself. The underlying felony-here the injury to a child-supplies the

131. Kuykendall, 609 S.W.2d at 796.

132. Id. at 795.

133. Id.

134. Ex parte Easter, 615 S.W.2d 719 (Tex. Crim. App. 1981). 
necessary culpable mental state." ${ }^{\prime 35}$ The court supported this conclusion with the language of the Practice Commentary to the effect that section 19.02(3) promised little change "in practice" from prior law, ${ }^{136}$ and the "wellsettled" principle that "one who, intending to commit a fel ony, accidentally commits another felony, is guilty of the felony actually committed." ${ }^{137}$ This archaic principle of strict liability for all unintended consequences of felonies is, of course antithetical to the Model Penal Code's culpability scheme. It is a form of the confusing doctrine of "general intent" that the Model Penal Code's element analysis was designed to eliminate. The principle was stated in the 1979 case of Honea v. State in which, the court added that "the intent to commit the contemplated offense transfers to the offense in fact committed." 138 In support of this claim, however, the court cited only an irrelevant Code provision on the transfer of causal responsibility, not culpability. ${ }^{139}$ The Practice Commentary implies that this section does not even deal with the special causal issues arising in fel ony murder, referring the reader instead to the murder provision. ${ }^{140}$ The Honea and Easter decisions simply ignore the language of the M.P.C.inspired ${ }^{141}$ Code in preserving the pre-code jurisprudence of transferred intent.

Ignoring the implication of Kuykendall that felony murder requires a culpable mental state of negligence, lower courts have repeated the transferred intent formula

135. Id. at 721 .

136. Id. (citing Kuykendall, which in turn cites the practice comment).

137. Id. at 720 (citing Honea v. State, 585 S.W.2d 681, 685 (Tex. Crim, App. 1979)).

138. Id.

139. See id. (citing V.T.C.A. Title 5, Section 6.04 (a):

his conduct... (b) A person is nevertheless criminally responsible for causing a result if the only difference between what actually occurred and what he desired, contemplated or risked is that: (1) a different offense was committed; or a person is criminally responsible if the result would not have occurred but for (2) a different person or property was injured, harmed, or otherwise affected.).

140. V.T.C.A. 1 Penal (1974) 94 (Section 6.04 practice cmt.).

141. Seth S. Searcy III, Foreword, V.T.C.A. 1 Penal (1974) XV. 
of Rodriguez and Easter, at least in dicta. Thus in Mackey v. State, ${ }^{142}$ a court upheld a felony murder conviction appealed because of a failure to instruct on the lesser included offense of negligent homicide. While the holding was that defendant's act dangerous to life (leaving an infant by the side of the road) was undoubtedly committed in the course and in furtherance of his auto theft felony, the court unnecessarily implied that the entire mens rea of murder was supplied by the mens rea of auto theft, without considering the possibility of a compound mens rea. ${ }^{143}$

Similarly, in Cooper v. State, ${ }^{144}$ a court cited Mackey and Rodriguez for the proposition that "in felony murder cases, the culpable mental state for the act of murder is supplied by the mental state accompanying the underlying committed or attempted felony giving rise to the act."145 Yet if Kuykendall remains authoritative, this proposition is only half true: Since the negligence implied by the commission of an act clearly dangerous to human life cannot by itself suffice to establish murder, the additional culpability required for murder is supplied by the mental state accompanying the predicate felony. In any case, the transferred intent formula is dictum in Cooper. The trial court had instructed the jury to find Cooper liable for murder in the course of the felony of injury to a child, only if he both recklessly injured the child and recklessly committed an act clearly dangerous to human life. ${ }^{146}$ On appeal, the Cooper court overturned the conviction because the trial judge erroneously instructed the jury that acting recklessly meant acting recklessly with respect to a result or circumstance, whereas Cooper could only be guilty of recklessly committing an act clearly dangerous to life in the course of recklessly injuring a child if he were reckless with respect to results alone. ${ }^{147}$ But which results? Only injury?

142. 811 S.W.2d 643 (Tex. App. 1991).

143. See id. at 645.

144. 842 S.W.2d 414 (Tex. App. 1992).

145. Id. at 421.

146. See id. at $419-20$.

147. See id. at 421. 
Or also death? The court does not clarify whether it accepted the trial court's assumption that the act dangerous to life requires its own mens rea. Nor does it clarify whether it understood Rodriguez to restrict predicate felonies to those involving recklessness with respect to death. Thus Cooper left the mens rea of felony murder in Texas more confused than ever.

A recent case, also entitled State v. Rodriguez, ${ }^{148}$ involves an extensive discussion of the development of Texas felony murder law. While the case concerns the issue of merger rather than the mens rea of felony murder, the court rejects the language of "transferred intent" as a confusing "fiction" and instead explains section 19.02(b)(3) as "a separate mode of first degree murder, a distinct crime for which the killing did not have a separate mens rea element apart from the felony. No transferred intent was required." ${ }^{149}$ The court further commented:

The more recent trend has been to abandon the fiction of implied malice.... Most statutes and courts now frankly characterize a homicide as murder if the killer acted with reckless and wanton disregard of an obvious risk to human life. This is exactly what our legislature did in enacting the third mode of first degree murder in section 19.02 (b)(3). ${ }^{150}$

Unfortunately, however, the court does not clarify to what objective el ement-the predicate felony, the dangerous act, or the resulting death-this requirement of a reckless and wanton disregard of an obvious risk to human life attaches. Nor does it clarify the role of the default rules. With this second Rodriguez decision, however, the Texas courts appear to have shifted from a transferred intent variant of an implied culpability strategy, to a dangerousness variant.

Oregon has a homicide default rule and a negligence rule that appears pervasive. This rule resembles Model Penal Code section 2.02(1) except that instead of saying

148. 953 S.W.2d 342 (Tex. App. 1997).

149. Id. at 349.

150. Id. at 353-54. 
"unless he acted purposely, knowingly, recklessly or negligently, as the law may require, with respect to each material element of the offense," person acts with a culpable mental state with respect to each material element of the offense that necessarily requires a culpable mental state."152 Oregon punishes "criminal homicide" as murder if committed in the course of various forms of the traditional enumerated felonies plus arson, bombing, escape, kidnapping, and "compelling prostitution." 153 Oregon also provides an affirmative defense for accomplices to the felony who neither kill nor foresee the homicidal act. ${ }^{154}$ The Oregon courts have not

151. Model Penal Code § 2.02(1) (Official Draft and Revised Comments 1980).

152. Or. Rev. Stat. § 161.095 (1999).

153. Id. § $163.115(1)$ :

Except as provided in $\S 163.118$ and 163.125 , criminal homicide constitutes murder: ... (b) When it is committed by a person, acting either alone or with one or more persons, who commits or attempts to commit any of the following crimes and in the course of and in furtherance of the crime the person is committing or attempting to commit, or during the immediate flight therefrom, the person, or another participant if there be any, causes the death of a person other than one of the participants:

(A) Arson in the first degree as defined in § 164.325;

(B) Criminal mischief in the first degree by means of an explosive as defined in § 164.365;

(C) Burglary in the first degree as defined in § 164.225;

(D) Escape in the first degree as defined in § 162.165;

(E) Kidnapping in the second degree as defined in § 163.225;

(F) Kidnapping in the first degree as defined in $\S 163.235$;

(G) Robbery in the first degree as defined in § 164.415;

(H) Any fel ony sexual offense in the first degree defined in this chapter;

(I) Compelling prostitution as defined in $\S 167.017$; or

(J ) Assault in the first degree, as defined in $\S 163.185$, and the victim is under 14 years of age, or assault in the second degree, as defined in $\S$ 163.175 (1)(a) or (b), and the victim is under 14 years of age; . . .

154. See id. § 163.115(3):

It is an affirmative defense to a charge of violating subsection (1)(b) of this section that the defendant:

(a) Was not the only participant in the underlying crime;

(b) Did not commit the homicidal act or in any way solicit, request, command, importune, cause or aid in the commission thereof;

(c) Was not armed with a dangerous or deadly weapon;

$\mathrm{Had}$ no reasonable ground to believe that any other participant was armed 
treated the homicide default rule as having any significance independent of the requirement of a dangerous predicate felony. In the 1981 case of State $v$. Reams, the Oregon Supreme Court reasoned that predicating felony murder liability on enumerated crimes was an effort to limit liability to killing in the course of crimes the legislature deemed inherently dangerous to human life. ${ }^{155}$ Yet in State v. Burnell, the Court of Appeals stated that "the fel ony murder statute... requires an intent to commit the underlying felony, but has no mens rea causation of death requirement." ${ }^{156}$ In effect, the Oregon scheme treats killing in the course of a dangerous felony as requiring the jury to find at least negligence, absent rebuttal by means of the affirmative defense. By contrast, the Model Penal Code treats killing in the course of a dangerous felony as permitting - but not requiring-a finding of recklessness and extreme indifference to human life.

All four of our four pervasive negligence states condition felony murder on inherently dangerous felonies or, in the case of Texas, felonies committed by means of acts inherently dangerous to life. Thus all four felony murder statutes are basically compatible with the default rules. Only in Texas has the judiciary explicitly considered the significance of the state's general default rules for the felony murder provision. Even while acknowledging the applicability of these default rules, the Texas courts have resisted them by reverting to pre-Code concepts of "transferred intent." The recent Rodriguez decision, however, abandons transferred intent in favor of characterizing the Texas felony murder rule as implying culpability through the requirement of an act dangerous to life.

\footnotetext{
with a dangerous or deadly weapon; and

(d) Had no reasonable ground to believe that any other participant intended to engage in conduct likely to result in death.

155. 636 P.2d 913, 917 (Or. 1981).

156. 877 P.2d 1228, 1229 (Or. Ct. App. 1994).
} 


\section{NonpervasiveStates}

Finally, let us consider the problem of interpreting felony murder provisions in four states with nonpervasive culpability default rules: Kansas, Ohio, Utah, and Colorado

Kansas predicates first degree murder on either intentional and premeditated killing or killing in the commission, attempt, or flight from enumerated "inherently dangerous" felonies. ${ }^{157}$ There is no second

157. Kan. Stat. Ann. § 21-3401 (1981):

Murder in the first degree. Murder in the first degree is the killing of a human being committed:

(a) Intentionally and with premeditation; or (b) in the commission of, attempt to commit, or flight from an inherently dangerous felony as defined in § 21-3436 and amendments thereto. . . .

$\S$ 21-3436. Inherently dangerous felony; definition. (a) Any of the following felonies shall be deemed an inherently dangerous felony whether or not such felony is so distinct from the homicide alleged to be a violation of subsection (b) of section 21-3401 and amendments thereto as not to be an ingredient of the homicide alleged to be a violation of subsection (b) of section 21-3401 and amendments thereto:

(1) Kidnapping, as defined in section 21-3420 and amendments thereto;

(2) aggravated kidnapping, as defined in section 21-3421 and amendments thereto;

(3) robbery, as defined in section 21-3426 and amendments thereto;

(4) aggravated robbery, as defined in section 21-3427 and amendments thereto;

(5) rape, as defined in section 21-3502 and amendments thereto;

(6) aggravated criminal sodomy, as defined in section 21-3506 and amendments thereto;

(7) abuse of a child, as defined in section 21-3609 and amendments thereto;

(8) felony theft under subsection (a) or (c) of section 21-3701 and amendments thereto;

(9) burglary, as defined in section 21-3715 and amendments thereto;

(10) aggravated burglary, as defined in section 21-3716 and amendments thereto;

(11) arson, as defined in section 21-3718 and amendments thereto;

(12) aggravated arson, as defined in section 21-3719 and amendments thereto;

(13) treason, as defined in section 21-3801 and amendments thereto;

(14) any felony offense as provided in section $65-4127$ a, $65-4127 b$ or $65-$ 4159 or 1995 Supp. section 65-4160 through section 65-4164 and 
degree fel ony murder. ${ }^{158}$ Kansas requires criminal intent or recklessness for every offense, with intent as the default mental state but does not specify that a culpable mental state is required for every element.

These default rules were introduced into the Kansas Code in 1969, before Kansas restricted felony murder to enumerated felonies. Kansas cases varied in their construction of the culpability required for felony murder until the legislature predicated the offense on inherently dangerous felonies. In State v. Osbey, decided four years after the introduction of the default rules, the Kansas Supreme Court held that while the felony substitutes for premeditation in raising murder to the first degree, the jury must still find malicious killing in order to find murder. The court approved an instruction to that effect, which in turn defined maliciously as "willfully" (and hence "intentionally") doing a "wrong act." "159 In the companion

amendments thereto; and

(15) any felony offense as provided in section 21-4219 and amendments thereto.

(b) Any of the following felonies shall be deemed an inherently dangerous felony only when such felony is so distinct from the homicide alleged to be a violation of subsection (b) of section 21-3401 and amendments thereto as to not be an ingredient of the homicide alleged to be a violation of subsection (b) of section 21-3401 and amendments thereto:

(1) murder in the first degree, as defined in subsection (a) of section 213401 and amendments thereto;

(2) murder in the second degree, as defined in subsection (a) of section

21-3402 and amendments thereto;

(3) voluntary manslaughter, as defined in subsection (a) of section 213403 and amendments thereto;

(4) aggravated assault, as defined in section 21-3410 and amendments thereto;

(5) aggravated assault of a law enforcement officer, as defined in section 21-3411 and amendments thereto;

(6) aggravated battery, as defined in subsection (a)(1) of section 21-3414 and amendments thereto; and

(7) aggravated battery against a law enforcement officer, as defined in section 21-3415 and amendments thereto.

158. See id. § 21-3402.

159. 517 P.2d 141, 148-49 (Kan. 1973). This formula is somewhat ambiguous: 
case of State v. Reed, however, the court implied that any homicide in the course of, and directly resulting from, the commission of a felony inherently dangerous to human life sufficed. ${ }^{160}$ In State v. Branch, the court was forced to clarify the mens rea of felony murder when confronted with a defendant's claim to have shot a victim "accidentally" during an armed robbery. Rejecting defendant's claim as irrelevant, the court held that "a requirement of the felony murder rule is that the participants in the felony could reasonably foresee or expect that a life might be taken in perpetration of such a felony." Murder liability is imposed on those who commit dangerous felonies "knowing full well the possible tragic results." ${ }^{161}$ Thus an inherently dangerous felony was necessary to demonstrate a mental state of recklessness or negligence. In State v. Smith, the court understood Branch to require actual foresight on the part of the participants, of the possibility of a death, suggesting recklessness. ${ }^{162}$ In State v. Underwood, however, the court followed the reasoning of Wharton's treatise $^{163}$ that the felony murder doctrine involves a "transfer" of intent from a felony dangerous to human life to a resulting death, and held that the offense of possession of a firearm by an ex-felon could not serve as a predicate felony because it was neither foreseeably dangerous nor a crime of intent. ${ }^{164}$ The court further held that the dangerousness of an offense should be viewed in the abstract, so that if the offense is not generally dangerous to human life, it cannot serve as a predicate felony. ${ }^{165}$ In State v. Lashley, the court characterized an instruction's requirement that the prosecution prove malice in a felony

could one kill maliciously by willfully committing a wrongful act that accidentally causes death? Such a reading of "malicious killing" seems strained, but not impossible.

160. 520 P.2d 1314, 1316 (Kan. 1974).

161. State v. Branch, 573 P.2d 1041, 1042 (Kan. 1978).

162. 594 P.2d 218 (Kan. 1979).

163. See 2 Wharton's Criminal Law $\S 146$, at 210 (14th ed. 1979).

164. See State v. Underwood, 615 P.2d 153, 160-61 (Kan. 1980).

165. Id. at 162 . 
murder case as "erroneous." ${ }^{\prime \prime 66}$ But it also understood the Underwood court to have required that predicate felonies fit into a statutory category of "forcible felonies," despite concluding oddly that theft should be viewed as a forcible felony. ${ }^{167}$ A later decision held that as there is nothing inherently forcible or violent about the sale of cocaine or its accompanying intent, it cannot be a predicate felony. ${ }^{168}$ "The intent being transferred or presumed is not recklessness-it is premeditation, malice, etc. The determinative factor of [prior cases precluding felony murder liability] was ... that there was no active violence as part of the crimes; no threat of violence against the persons present." ${ }^{\prime 69}$

Ultimately, in 1992, the legislature accepted Lashley's invitation to amend the statute to require an inherently dangerous felony. It enumerated these felonies and included both theft and drug-dealing. In sum, the caselaw in Kansas appeared to have required some level of culpability with respect to death. The required culpability appeared to be recklessness or negligence rather than the default standard of intent, but the courts characterized the requisite culpability as a transferred intent to do violence. Such a "transferred intent" notion may even be legitimate in applying a nonpervasive culpability requirement and default rule. Throughout this jurisprudence, however, the Kansas courts have made no reference to the default rules.

Like Illinois, New J ersey, and Alabama, Ohio courts have drawn inferences about the legislative history of homicide statutes in order to construe their mental elements. Ohio has a recklessness default rule but no pervasive culpability rule. Until 1998, Ohio had no felony murder, based on the 1857 case of Robbins v. State, in which the Ohio Supreme Court read the murder statute to require purpose to kill for murders in the perpetration or

166. 664 P.2d 1358 (Kan. 1983).

167. See id. at 1368-70; see also State v. Hoang, 755 P.2d 7, 9 (Kan. 1988); State v. Wesson 802 P. 2d 574, 579 (Kan. 1990).

168. See State v. Wesson, 802 P.2d at 579.

169. Id. 
attempt of a felony. ${ }^{170}$ Ohio recently revised its homicide provisions, creating a crime of felony murder for the first time, defined as "caus[ing] the death of another as a proximate result of the offender's committing or attempting to commit an offense of violence that is a felony of the first or second degree" other than manslaughter. ${ }^{171}$

Ohio courts have not yet construed this provision. Yet the new fel ony murder provision mimics the language in an older felony manslaughter provision, which however applies to all felonies, not only especially heinous ones. In State v. Losey, an Ohio appeals court construed this felony manslaughter provision as follows:

In rejecting the concept of reckless homicide and opting instead to retain unlawful act manslaughter in R.C. 2903.04, the General Assembly manifested its purpose to adopt the traditional concept of transferred intent in the instance of involuntary manslaughter. In doing so, the General Assembly specified the "degree of culpability" alluded to in R.C. 2901.21(B). ${ }^{172}$

The court here adverts to the fact that the Code's drafting committee proposed, and one house of the Ohio legislature passed, a reckless manslaughter statute largely based on the Model Penal Code provision but that the other house rejected this in favor of the language ultimately adopted. ${ }^{173}$ This is a rare instance of an explicit effort to reconcile

170. 8 Ohio St. 131 (1857).

171. Ohio Rev. Code Ann. § 2903.02 (1999):

(A) No person shall purposely cause the death of another or the unlawful termination of another's pregnancy.

(B) No person shall cause the death of another as a proximate result of the offender's committing or attempting to commit an offense of violence that is a felony of the first or second degree and that is not a violation of section

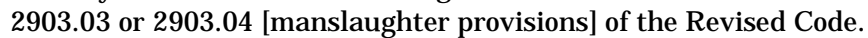

(C) Division (B) of this section does not apply to an offense that becomes a felony of the first or second degree only if the offender previously has been convicted of that offense or another specified offense.

(D) Whoever violates this section is guilty of murder. . . .

172. 491 N.E.2d 379, 384 (Ohio Ct. App. 1985).

173. See J effrey M. Goldsmith, Involuntary Manslaughter: Review and Commentary on Ohio Law, 40 Ohio St. L.J . 569 (1979). 
transferred intent with a mens rea default rule. Because the Ohio default rule is nonpervasive, the court was able to avoid characterizing the felony manslaughter provision as a strict liability offense, and claiming that the statute "plainly indicated" a purpose of imposing strict liability. Thus Ohio, like Kansas, adopts the transferred intent version of the implied culpability strategy. In both cases, the strategy is defensible because both states have nonpervasive default rules. The Losey court also construed "proximate cause" to require "foreseeability" and "reasonable inevitability"174 but found it present where a victim died of a heart attack on discovering that a door had been forced by burglars who had left the scene. ${ }^{175}$

Since 1995, Utah has recognized only one degree of noncapital murder. The Utah Code includes within this category causing the death of anyone other than an accomplice, in the commission or attempt of a number of enumerated felonies. These include various forms of the traditional enumerated felonies plus kidnapping, and child abuse. ${ }^{176}$ Utah presents an ambiguous scheme of default rules. They require that every offense involve "acting" with a culpable mental state unless the statute defining the offense indicates a legislative intent to impose liability without proof of any culpable mental state. It is of course possible to argue that the failure to specify any mental element for felony murder implies an intention to impose strict liability, particularly where other forms of murder

174. 491 N.E.2d at 382

175. Accord Stanley v. Turner, 6 F.3d 399 (6th Cir. 1993).

176. See Utah Code Ann. § 76-5-203 (1999):

Murder.

(1) Criminal homicide constitutes murder if the actor: . . .

(d) while in the commission, attempted commission, or immediate flight from the commission or attempted commission of aggravated robbery, robbery, rape, object rape, forcible sodomy, or aggravated sexual assault, aggravated arson, arson, aggravated burglary, burglary, aggravated kidnapping, kidnapping, child kidnapping, rape of a child, object rape of a child, sodomy upon a child, forcible sexual abuse, sexual abuse of a child, aggravated sexual abuse of a child, or child abuse, as defined in Subsection 76-5-109 (2)(a), when the victim is younger than 14 years of age, causes the death of another person other than a party as defined in Section 76-2-202; 
are defined by reference to culpable mental states. Militating against this reading of the felony murder provision is the definition of criminal homicide as causing death with intent, knowledge, recklessness, negligence or some other culpable mental state specified in the statute defining the offense. ${ }^{177}$ Since no such culpable mental state is specified in the felony murder provision, felony murder arguably requires at least negligence. But this is speculation: There are no cases construing the contemporary statutory language with respect to mental culpability.

Colorado combines a nonpervasive negligence default rule and a necessarily involved culpability rule. Colorado's felony murder statute is unusual in that it punishes the commission or attempt of enumerated dangerous felonies when death "is caused" in furtherance of such a felony "by anyone." 178 It provides the New York affirmative defense for accomplices who neither commit nor have reason to foresee the killing. ${ }^{179}$ In addition, Colorado punishes as

177. See id. § 76-5-201:

Criminal homicide-Elements-Designations of offenses.

(1) (a) A person commits criminal homicide if he intentionally, knowingly, recklessly, with criminal negligence, or acting with a mental state otherwise specified in the statute defining the offense, causes the death of another human being, including an unborn child.

(b) There shall be no cause of action for criminal homicide for the death of an unborn child caused by an abortion.

(2) Criminal homicide is aggravated murder, murder, manslaughter, child abuse homicide, homicide by assault, negligent homicide, or automobile homicide.

178. Colo. Rev. Stat. Ann. § 18-3-102 (West 1999):

Murder in the first degree.

(1) A person commits the crime of murder in the first degree if: . . .

(b) Acting either alone or with one or more persons, he commits or attempts to commit arson, robbery, burglary, kidnapping, sexual assault in the first or second degree as prohibited by section 18-3-402 or 18-3-403, or a class 3 felony for sexual assault on a child as provided in section 18-3-405 (2), or the crime of escape as provided in section 18-8-208, and, in the course of or in furtherance of the crime that he is committing or attempting to commit, or of immediate flight therefrom, the death of a person, other than one of the participants, is caused by anyone. ...

179. See id. § 18-3-102: 
murder the distribution of drugs to a child that results in the child's death. ${ }^{180}$ Consistent with Colorado's necessarily involved rule, though not necessarily because of it, Colorado's courts employ a "proximate cause" standard of causation in felony murder cases, according to which the death must be the "natural and probable" consequence of an enumerated dangerous felony and must not have depended upon an "unforeseeable" "supervening cause" independent of the felony. ${ }^{181}$ Overall, the legal framework in Colorado closely resembles that in New York, despite the fact that New York's culpability default rule is pervasive and Colorado's is not.

The significant difference that nonpervasive default rules make is that they permit resort to the transferred intent version of the implied culpability stratagem. This feature of nonpervasive default rules for interpreting all

Murder in the first degree: (2) It is an affirmative defense to a charge of violating subsection (1) (b) of this section that the defendant:

(a) Was not the only participant in the underlying crime; and

(b) Did not commit the homicidal act or in any way solicit, request, command, importune, cause, or aid the commission thereof; and

(c) Was not armed with a deadly weapon; and

(d) Had no reasonable ground to believe that any other participant was armed with such a weapon, instrument, article, or substance; and

(e) Did not engage himself in or intend to engage in and had no reasonable ground to believe that any other participant intended to engage in conduct likely to result in death or serious bodily injury; and

(f) Endeavored to disengage himself from the commission of the underlying crime or flight therefrom immediately upon having reasonable grounds to believe that another participant is armed with a deadly weapon, instrument, article, or substance, or intended to engage in conduct likely to result in death or serious bodily injury.

180. See id. § 18-3-102:

Murder in the first degree.

(1) A person commits the crime of murder in the first degree if : . .

(e) He or she commits unlawful distribution, dispensation, or sale of a controlled substance to a person under the age of eighteen years on school grounds as provided in section 18-18-407 (2), and the death of such person is caused by the use of such controlled substance. . . .

181. See People v. Calvaresi, 534 P.2d 316 (Colo. 1975) (articulating supervening cause standard); People v. Bowman 669 P.2d 1369 (Colo. 1983) (applying standard to fel ony murder). 
offense definitions seems less relevant in a jurisdiction like Utah, however, that also has a homicide default rule.

\section{Summary of Default Rules in the Courts}

What patterns emerge from this review of felony murder cases in default rule states? The most striking pattern is the rarity of any reference to, or reliance upon, the default rules in construing felony murder provisions that are silent as to mens rea. Only Texas has a developed body of jurisprudence regarding the applicability of these default rules. And even in Texas, where courts have acknowledged the applicability of the default rules, they appear to have systematically subverted or misunderstood these default rules and reverted to the idea of transferred intent. Outside of Texas, the only other state judiciary to have explicitly confronted the default rules is New J ersey, where the Court found a legislative intent to impose strict liability. Neither Texas nor New J ersey have explicitly acknowledged the applicability of their homicide default rules. By contrast, Pennsylvania courts have upheld a jury instruction based on the homicide default rule, but ignored the applicability of a general recklessness default rule. An Ohio court has explicitly considered the applicability of a general default rule to felony manslaughter, but, like Texas, it has subverted that rule by perpetuating the archaic notion of transferred intent. Presumably, the Ohio courts will apply this approach to felony murder.

Courts in five other states-Illinois, Missouri, Alaska, Oregon, and Kansas-have opined on the mental element of felony murder, without referring to the default rules. Like courts in Texas and Ohio, Kansas courts relied on the notion of transferred intent. But like the most recent Rodriguez decision in Texas, Kansas courts have also relied on the argument that the dangerousness of the predicate felony supplies culpability. Courts in New York and Colorado have considered the culpability required for fel ony murder only indirectly, under the rubric of proximate 
causation of death. Courts in North Dakota, Delaware, ${ }^{182}$ Alabama, and Utah have never considered whether culpability is required for felony murder offenses.

Courts in Illinois, Alaska, and Alabama have been spared a confrontation with the default rules by legislative commentaries that clarified legislative intent with respect to the mental element of felony murder. All three legislative comments may be read as expressions of the argument that a dangerous predicate felony implies the culpability with respect to death demanded by a pervasive culpability requirement, although Alaska's may also be read simply as an expression of legislative intent to impose strict liability for deaths caused by dangerous felonies.

\section{CONCLUSION}

The Model Penal Code conditions felony murder on gross recklessness, rebuttably implied by causing death in the course of a dangerous fel ony. This explicit requirement of recklessness flows from the Model Penal Code's overall culpability scheme which requires culpability with respect to every objective element for all serious offenses and which makes recklessness the default culpable mental state. While half of the states have adopted some version of the Model Penal Code's default culpability rules, however, very few states have adopted its felony murder provision. Yet this does not necessarily mean that they have utterly rejected the Model Penal Code approach to felony murder, since faithful application of the default rules to a traditional felony murder provision yields substantially the same regime.

A large number of legislatures-or code drafting commissions-appear to have noticed the applicability of default rules to felony murder provisions. Montana explicitly exempted felony murder from its default rules. Hawaii, a recklessness default state, required intent for all

182. This claim is limited to Delaware's escape-murder provision which, unlike its regular felony murder provision, contains no mens rea term. 
murder. Arkansas, another recklessness default state, required at least gross recklessness. Delaware, a recklessness default state, required negligence for felony murder (excepting its escape murder provision), while Tennessee first required recklessness and later declared that killing in the course of enumerated dangerous felonies would be a strict liability crime. New Hampshire and Kentucky, both negligence default states, required at least gross recklessness for all murders, while Maine explicitly imposed its default standard of negligence for felony murder. Legislative drafting commissions in Alaska, Alabama, Illinois, and New J ersey addressed the issue in commentaries rather than in the statutes themselves. In New Jersey, an intent default state, the drafting commission characterized fel ony murder as a strict liability offense. In Alaska, a recklessness default state, the drafting commission issued a more ambiguous statement that could be read either as imposing strict liability or as asserting that recklessness is implied in the commission of dangerous felonies. In Illinois, the drafting commission found the default culpability standard of recklessness implied in violent predicate felonies, and in Alabama a drafting commission found the default standard of negligence implied by dangerous felonies.

These extensive efforts to address the mental element of felony murder show that code drafters often understood that they were constructing systematic codes, governed by principles of culpability and rules of interpretation. And these legislative efforts imply an understanding that the default rules would apply to felony murder unless the mental element of felony murder were specified either in the code or its accompanying comments. The performance of the legislative drafting commissions yields another pattern as well. None of the codes or comments employs the notion of transferred intent in connection with felony murder.

By contrast, courts have shown little awareness that the new codes require application of the default rules to offense definitions that are silent with respect to 
culpability. Courts in only four states have referred to the default rules in determining the mental element of the offense of killing in the course of a felony and two of these have subverted the default rules by invoking the outmoded concept of transferred intent.

It may be that judicial application of the default rules would seldom make a difference, because they would seldom require more than negligence in states that have not legislatively defined the mental element of felony murder.

Only nine states have default rules requiring recklessness or intent that are clearly pervasive. ${ }^{183}$ In seven of these nine states, the mental element of felony murder has been legislatively determined, either in the statute or in an accompanying commentary-though of course these commentaries themselves require interpretation. The two exceptions are North Dakota, whose courts have not yet considered the question; and Pennsylvania, one of whose courts has plausibly treated felony murder as a species of criminal homicide requiring negligence.

The remaining states have either default rules that courts could interpret as nonpervasive or negligence default rules. In states with nonpervasive default rules, courts could argue that the requisite culpability was supplied by the predicate felony, perhaps on a traditional "transferred intent" theory. In states with negligence default rules, courts could argue that the requisite culpability was supplied by an inherently dangerous predicate fel ony or a dangerous act committed in the course of a felony. Since most states limit felony murder to dangerous felonies anyway, application of a negligence default rule would make little difference.

Thus, application of the default rules might work little change in the law of felony murder in most jurisdictions. Nevertheless it would make a difference in some. In North

183. Arkansas, Alaska, Delaware, Hawaii, Illinois, New J ersey, North Dakota, Pennsylvania, Tennessee. 
Dakota, for example, faithful application of the default rules would predicate felony murder on reckless causation of death. The same result would apply to escape murder in Delaware. Arguably, even a nonpervasive recklessness or intent default rule-like the ones in Kansas, Ohio, and Texas-should be applied to causing death in the course of a fel ony. A mens rea default rule is supposed to clarify the mental element of offenses. That was a major purpose of the Model Penal Code's culpability scheme, which rejected the confusing language of "transferred" or "general" intent. Yet a scheme of default rules cannot serve this purpose of clarification unless it defines the mental culpability required for each offense element. Courts in Kansas, Ohio, and Texas should construe their Code's ambiguous default rules to apply pervasively, to every element, including causation of death in felony murder. These courts should eschew the language of transferred intent, which has no place in construing a Model Penal Code inspired penal law. If the legislatures of these states do not wish to condition felony murder on recklessness or intent, they can specify the mental el ement of fel ony murder in their states' codes.

Missouri poses a more complicated case. Its default rule scheme defines the culpability attending every element, but requires that when culpable mental states are explicitly assigned to some elements, all other elements are strict liability. Yet, as the example of felony murder demonstrates, this scheme cannot achieve clarity because there are not always dear boundaries between offense definitions. Because Missouri does not condition felony murder on dangerous predicate felonies, it should condition fel ony murder on some form of culpability. Therefore, the Missouri courts should construe felony murder as a separate offense that is silent as to culpability. Such an offense requires application of the default culpable mental state of knowledge to all elements. If the legislature is unhappy with this result, it should revise the felony murder statute to condition fel ony murder on negligently or recklessly causing death in the commission or attempt of a felony dangerous to life. 
In states that combine negligence default rules with inherent dangerousness limitations on predicate felonies, applying the default rules would require no change in the law. Nevertheless, doing so would serve two useful purposes. First, it would remind the legislature, the public, and other courts, that mens rea default rules constitute an integral and authoritative part of a code and determine the meaning of its provisions. Second, applying such default rules to felony murder provisions would help clarify the nature of the modern offense of felony murder as a crime of culpability, conditioned on carelessly imposing a risk of death on others in the pursuit of felonious ends. Explicit application of the mens rea default rules would help lay to rest the persistent myth that felony murder is a crime of strict liability.

Mens rea default rules are the law. Courts should apply them explicitly. Doing so will better communicate the meanings of criminal code provisions to lawmakers and the electorate In turn, this will provoke the electorate and their representatives to communicate more clearly to the courts the criminal laws that they would like enforced. 